LA-14240-SR

Status Report

Approved for public release;

distribution is unlimited.

\title{
Evaluation of Macroinvertebrate Communities and Habitat for Selected Stream Reaches at Los Alamos National Laboratory
}

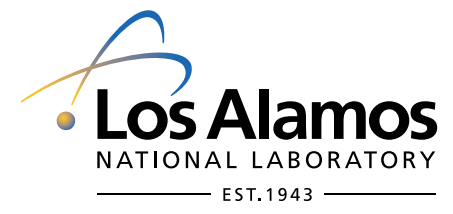

The World's Greatest Science Protecting America 


\section{Edited by Hector Hinojosa, Group IM-1}

Los Alamos National Laboratory, an affirmative action/equal opportunity employer, is operated by the University of California for the United States Department of Energy under contract W-7405-ENG-36.

This report was prepared as an account of work sponsored by an agency of the United States Government. Neither the Regents of the University of California, the United States Government nor any agency thereof, nor any of their employees make any warranty, express or implied, or assume any legal liability or responsibility for the accuracy, completeness, or usefulness of any information, apparatus, product, or process disclosed, or represent that its use would not infringe privately owned rights. Reference herein to any specific commercial product, process, or service by trade name, trademark, manufacturer, or otherwise does not necessarily constitute or imply its endorsement, recommendation, or favoring by the Regents of the University of California, the United States Government, or any agency thereof. The views and opinions of authors expressed herein do not necessarily state or reflect those of the Regents of the University of California, the United States Government, or any agency thereof. Los Alamos National Laboratory strongly supports academic freedom and a researcher's right to publish; as an institution, however, the Laboratory does not endorse the viewpoint of a publication or guarantee its technical correctness. 
LA-14240-SR

Status Report

Issued: August 2005

\section{Evaluation of Macroinvertebrate Communities and Habitat for Selected Stream Reaches at Los Alamos National Laboratory}

Lisa J. Henne

Kevin J. Buckley 



\section{Contents}

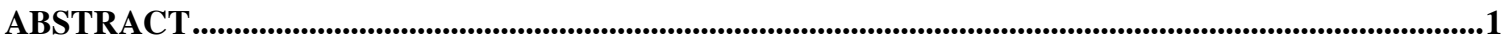

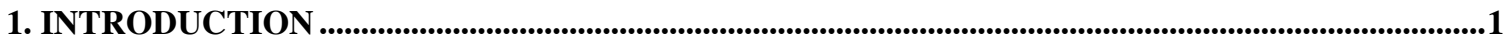

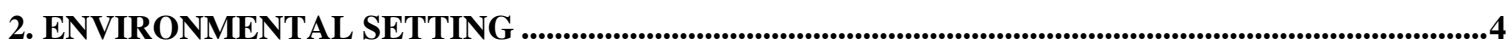

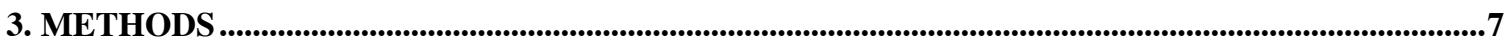

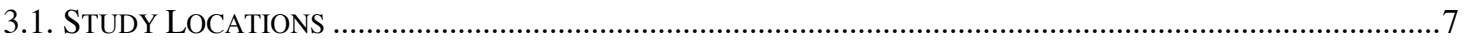

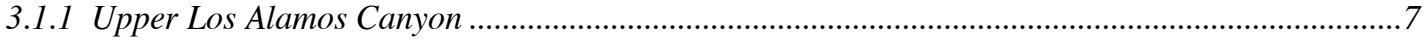

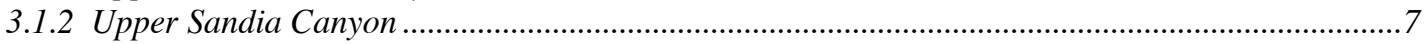

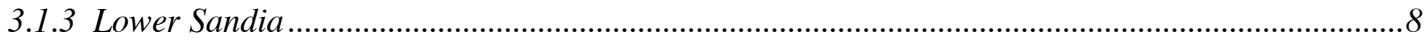

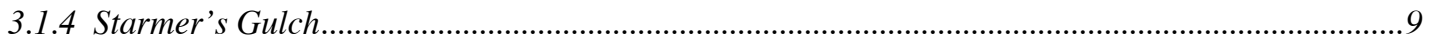

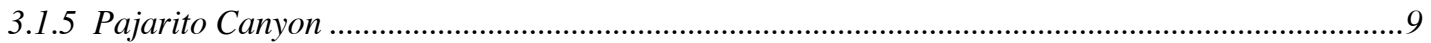

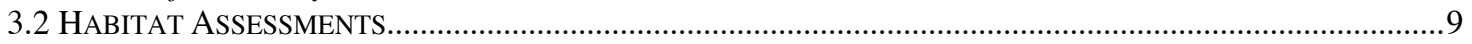

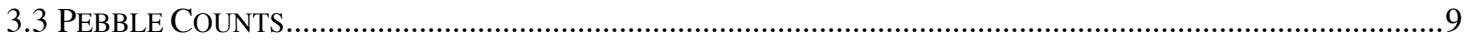

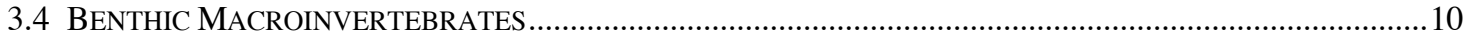

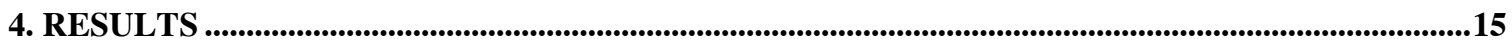

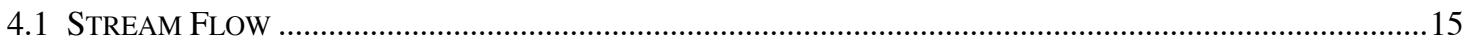

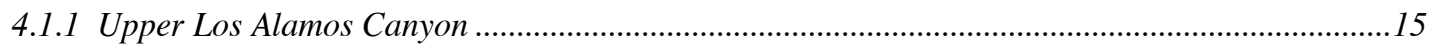

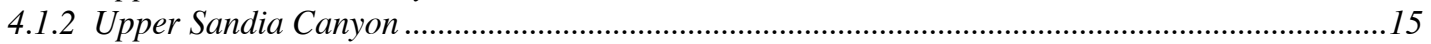

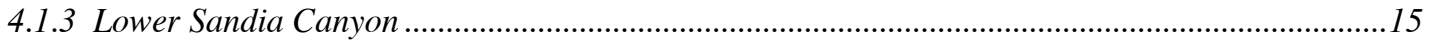

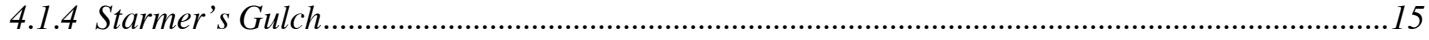

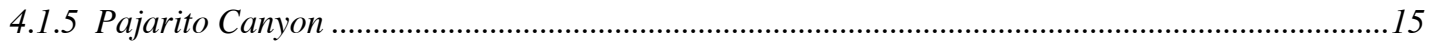

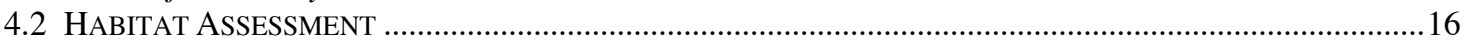

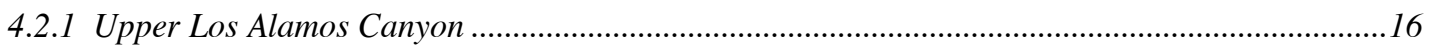

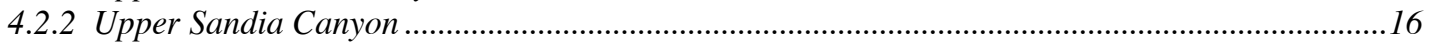

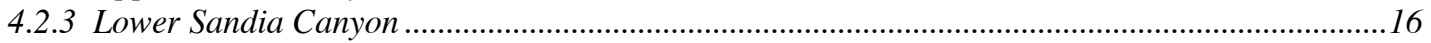

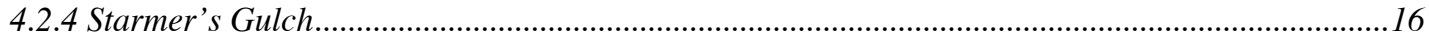

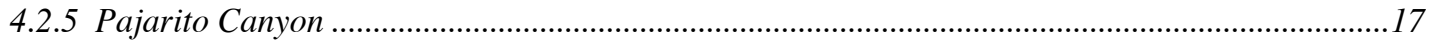

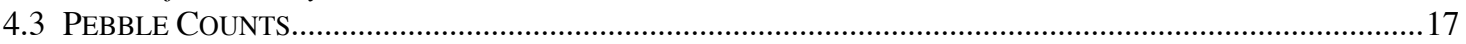

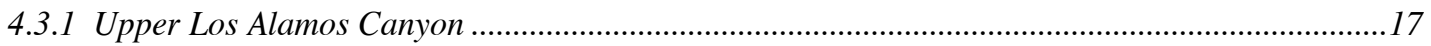

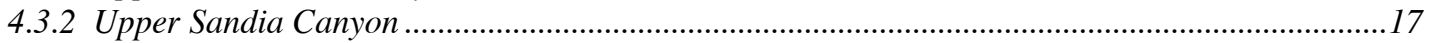

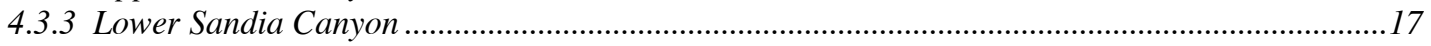

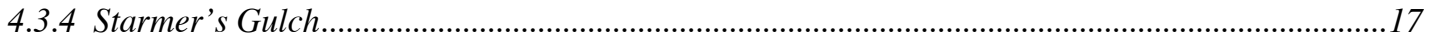

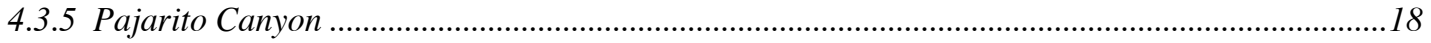

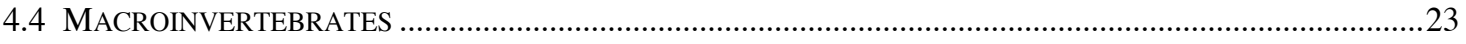

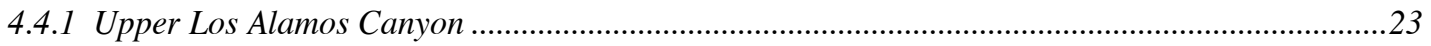

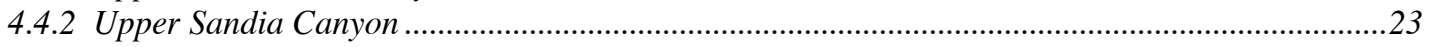

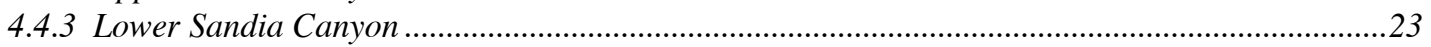

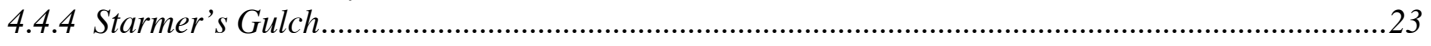

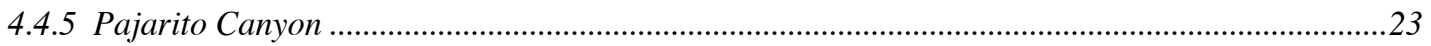

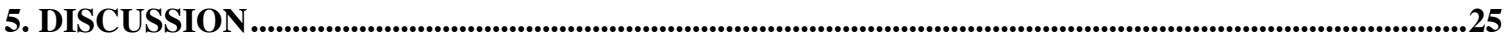

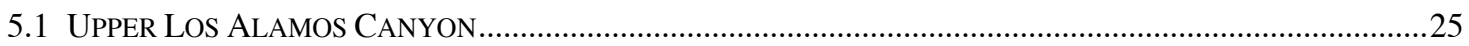

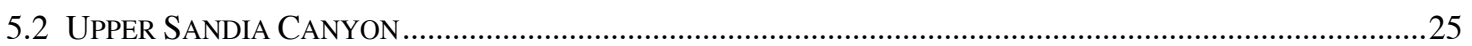

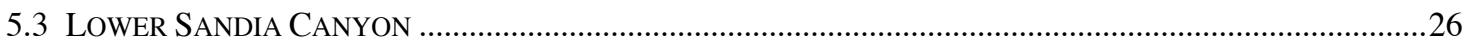

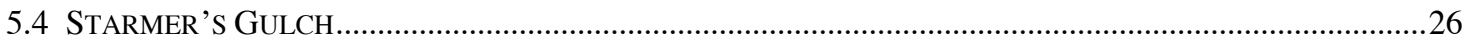

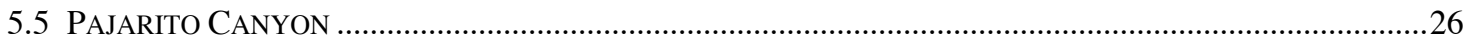

6. CONCLUSION ..............................................................................................................................................27

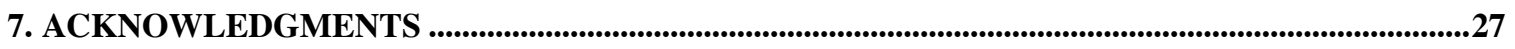

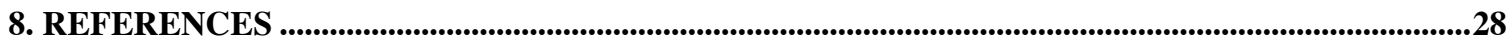




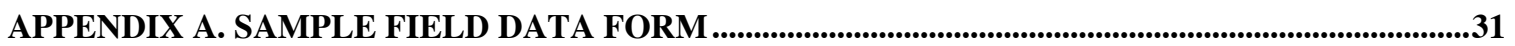

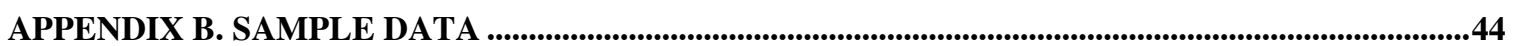

APPENDIX C. TAXA ATTRIBUTES AND TOLERANCE VALUES ......................................................49

APPENDIX D. MACROINVERTEBRATE METRICS.......................................................................................58

\section{List of Figures}

Figure 1. Location of Los Alamos National Laboratory …......................................5

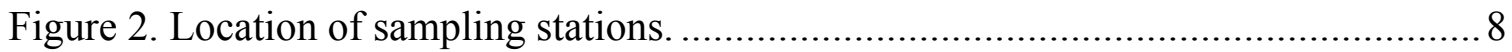

Figure 3. Starmer's Gulch, October 2002, showing Hess sampler used by LANL for collecting benthic macroinvertebrate samples .............................................. 11

Figure 4. Cumulative percent and size distributions for benthic substrate at upper Los

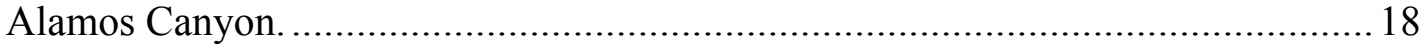

Figure 5. Cumulative percent and size distributions for benthic substrate at upper Sandia

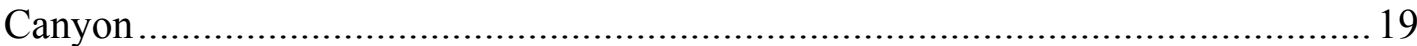

Figure 6. Cumulative percent pebble count data for lower Sandia Canyon....................20

Figure 7. Cumulative percent pebble count data for Starmer's Gulch. ......................... 21

Figure 8. Cumulative percent pebble count data for Pajarito Canyon..........................22

\section{List of Tables}

Table 1. Metrics used for evaluation of LANL sites and their hypothesized response to

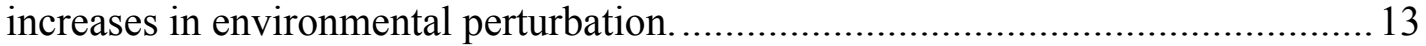

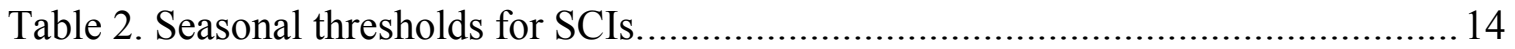

Table 3. Habitat assessment scores for biological monitoring locations at LANL. ......... 16

Table 4. Overall scores and ratings for macroinvertebrate communities based on NMED-

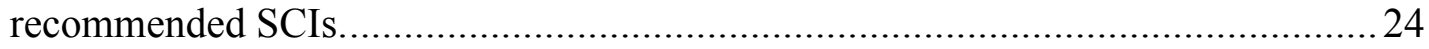




\section{Acronyms}

$\begin{array}{ll}\begin{array}{l}\text { ADEQ } \\ \text { cfs }\end{array} & \begin{array}{l}\text { Arizona Department of Environmental Quality } \\ \text { cubic feet per second }\end{array} \\ \text { D50 } & 50^{\text {th }} \text { cumulative percentile for particle size } \\ \text { ENV-ECO } & \text { Ecology Group } \\ \text { ENV-WQH } & \text { Water Quality and Hydrology Group } \\ \text { EPA } & \text { U.S. Environmental Protection Agency } \\ \text { LANL } & \text { Los Alamos National Laboratory } \\ \text { NMED } & \text { New Mexico Environment Department } \\ \text { RAWS } & \text { Remote Automated Weather Station } \\ \text { RBP } & \text { Rapid Bioassessment Protocol } \\ \text { SCI } & \text { Stream Condition Index } \\ \text { TA } & \text { Technical Area } \\ \text { USDA } & \text { U.S. Department of Agriculture }\end{array}$




\title{
EVALUATION OF MACROINVERTEBRATE COMMUNITIES AND HABITAT FOR SELECTED STREAM REACHES AT LOS ALAMOS NATIONAL LABORATORY
}

\author{
by
}

\author{
Lisa J. Henne and Kevin J. Buckley
}

\begin{abstract}
This is the second aquatic biological monitoring report generated by Los Alamos National Laboratory's (LANL's) Water Quality and Hydrology Group. The study has been conducted to generate impact-based assessments of habitat and water quality for LANL waterways. The monitoring program was designed to allow for the detection of spatial and temporal trends in water and habitat quality through ongoing, biannual monitoring of habitat characteristics and benthic aquatic macroinvertebrate communities at six key sites in Los Alamos, Sandia, Water, Pajarito, and Starmer's Gulch Canyons. Data were collected on aquatic habitat characteristics, channel substrate, and macroinvertebrate communities during 2001 and 2002.

Aquatic habitat scores were stable between 2001 and 2002 at all locations except Starmer's Gulch and Pajarito Canyon, which had lower scores in 2002 due to low flow conditions. Channel substrate changes were most evident at the upper Los Alamos and Pajarito study reaches. The macroinvertebrate Stream Condition Index (SCI) indicated moderate to severe impairment at upper Los Alamos Canyon, slight to moderate impairment at upper Sandia Canyon, and little or no impairment at lower Sandia Canyon, Starmer's Gulch, and Pajarito Canyon. Habitat, substrate, and macroinvertebrate data from the site in upper Los Alamos Canyon indicated severe impacts from the Cerro Grande Fire of 2000. Impairment in the macroinvertebrate community at upper Sandia Canyon was probably due to effluent-dominated flow at that site. The minimal impairment SCI scores for the lower Sandia site indicated that water quality improved with distance downstream from the outfall at upper Sandia Canyon.
\end{abstract}

\section{INTRODUCTION}

In 2001, the Water Quality and Hydrology Group (ENV-WQH) launched an aquatic biological monitoring program to generate impact-based assessments of habitat and water quality for Los Alamos National Laboratory (LANL) waterways. The monitoring program was designed to allow for the detection of spatial and temporal trends in water and habitat quality through ongoing, biannual monitoring of habitat characteristics and benthic aquatic macroinvertebrate communities at six key sites at the Laboratory. The Ecology Group (ENV-ECO) has supported this effort through assistance with fieldwork and data analysis. 
Physical and chemical analyses of water quality are useful but limited because they only provide information about the water quality at the time of sampling, and past conditions are not detected (Cairns et al. 1973). Biological monitoring complements physical and chemical analyses by providing information about recurring short-term or stable longterm environmental conditions, even if those conditions are not present at the time of sampling (Gaufin 1973). Aquatic macroinvertebrates are one of the most commonly sampled assemblages for biological monitoring in rivers and streams because they are abundant, diverse, and differ widely among taxa in their sensitivity to environmental disturbances (Chessman 1995).

Because aquatic macroinvertebrate community composition responds predictably to changes in water chemistry and physical stream conditions, measures of community composition provide information about environmental conditions (Cummins 1974, Rosenberg and Resh 1993). Measures of community composition that are known to respond predictably and reliably to environmental impacts (termed metrics) provide an indirect means to evaluate how human activities and other ecosystem processes impact water and habitat quality. Habitat assessments and substrate characterization provide context for the interpretation of macroinvertebrate data in addition to providing a means to measure habitat quality and stability.

Information gained through the biological monitoring program will be used to make informed decisions on watershed management practices, evaluate the impacts of activities on LANL property, and monitor trends associated with recovery from the Cerro Grande Fire. Biological and habitat data from the monitoring program are being gathered solely for LANL use and not for the purpose of meeting any existing or future federal or state requirement. However, there are numerous potential uses for the monitoring program data in a regulatory context. The New Mexico Environment Department (NMED) collects biological data on a 5- to 7-year cycle and uses those data in determining whether New Mexico water quality standards are being met and whether designated uses are being supported (NMED 2003). Data from the LANL aquatic monitoring program will allow the Laboratory to quickly detect and address any habitat or water quality problems that might occur during interim years in the NMED monitoring schedule, thereby improving the likelihood of remaining in regulatory compliance. Moreover, long-term data generated from the monitoring program will provide a better understanding of site potential than can be determined from the NMED's periodic sampling, and could be used to support arguments for the designation of reasonable and appropriate attainment levels.

In this report, we present results of our site assessments and macroinvertebrate analysis from samples collected in 2001 and 2002. NMED and Ford-Schmid (1996) provided us with macroinvertebrate data from studies conducted in the 1990s on or near LANL to use for temporal comparisons for our sites. Four of the NMED sampling locations (upper Los Alamos Canyon, lower Sandia Canyon, Pajarito Canyon, and Starmer's Gulch) coincided with or were near enough to our sampling locations that we included them in this report to provide information about how macroinvertebrate communities have changed between the sampling periods. These data represent pre-fire conditions and are useful for evaluating how sites were impacted by the Cerro Grande Fire. 
Our analysis of macroinvertebrate data differs from our previous report (Buckley et al. 2003) in that this report reflects recent advances in biocriteria development for New Mexico. Buckley et al. (2003) noted that statistical evaluation and calibration of macroinvertebrate metrics were needed to determine which of the numerous metrics that have been developed for other regions are valid for use in LANL's biogeographic setting. Without this validation of metrics, the utility of macroinvertebrate data is very limited. In addition, the lack of objective information about reference conditions and seasonal variations in the macroinvertebrate community limited our ability to interpret metric values. For this report, we have incorporated recommendations for metric selection and scoring made by Jacobi et al. (2004) under contract with the NMED. These recommendations are described further in the Methods section. 


\section{ENVIRONMENTAL SETTING}

LANL and the associated residential areas of Los Alamos and White Rock are located in Los Alamos County, north-central New Mexico, approximately 60 miles $(100 \mathrm{~km})$ northnortheast of Albuquerque and 25 miles $(40 \mathrm{~km})$ northwest of Santa Fe (Figure 1).

The 25,600-acre (10,240-ha) LANL site is situated on the Pajarito Plateau. This plateau is a series of finger-like mesas separated by deep east-to-west-oriented canyons that are cut by intermittent streams. Mesa tops range in elevation from approximately $7,800 \mathrm{ft}(2,400$ $\mathrm{m})$ on the eastern flanks of the Jemez Mountains to about 6,200 $\mathrm{ft}(1,900 \mathrm{~m})$ at their eastern termination above the Rio Grande.

Most of the finger-like mesas in the Los Alamos area are formed from Bandelier Tuff, which is composed of ash fall, ash-fall pumice, and rhyolite tuff. The tuff, ranging from nonwelded to welded, is more than $1,000 \mathrm{ft}(300 \mathrm{~m})$ thick in the western part of the plateau and thins to about $260 \mathrm{ft}(80 \mathrm{~m})$ eastward above the Rio Grande. Major eruptions in the volcanic center of the Jemez Mountains deposited the tuff about 1.2 to 1.6 million years ago.

On the western part of the Pajarito Plateau, the Bandelier Tuff overlaps onto the Tschicoma Formation, which consists of older volcanic materials that form the Jemez Mountains. The conglomerate of the Puye Formation underlies the tuff in the central plateau and near the Rio Grande. Chino Mesa basalts inter-finger with the conglomerate along the river. These formations overlay the sediments of the Santa Fe Group, which extend across the Rio Grande Valley and are more than 3,300 ft $(1,000 \mathrm{~m})$ thick. LANL is bordered on the east by the Rio Grande and is within the Rio Grande rift. Because the rift is slowly widening, the area experiences frequent minor seismic disturbances.

Los Alamos has a temperate, semiarid mountain climate. However, elevation strongly influences the climate, and the topography causes large temperature and precipitation differences in the area. The average annual precipitation in Los Alamos is 18.73 inches $(47.57 \mathrm{~cm})$. The summer rainy season accounts for $48 \%$ of the annual precipitation. During the July-September period, thunderstorms form when moist air from the Gulf of Mexico and the Pacific Ocean moves up the sides of the Jemez Mountains. These thunderstorms can bring large downpours, but sometimes they only cause strong winds and lightning. Hail frequently occurs from these rainy-season thunderstorms.

Surface water in the Los Alamos area occurs primarily as short-lived or intermittent reaches of streams. Perennial springs on the flanks of the Jemez Mountains supply base flow into upper reaches of some canyons, but the volume is insufficient to maintain surface flows across the LANL site before evaporation, transpiration, and infiltration deplete the flow. Runoff from heavy thunderstorms or heavy snowmelt reaches the Rio Grande several times a year in some drainage areas. Effluents from sanitary sewage, industrial waste-treatment plants, and cooling-tower blow-down enter some canyons at rates sufficient to maintain surface flows for varying distances. 


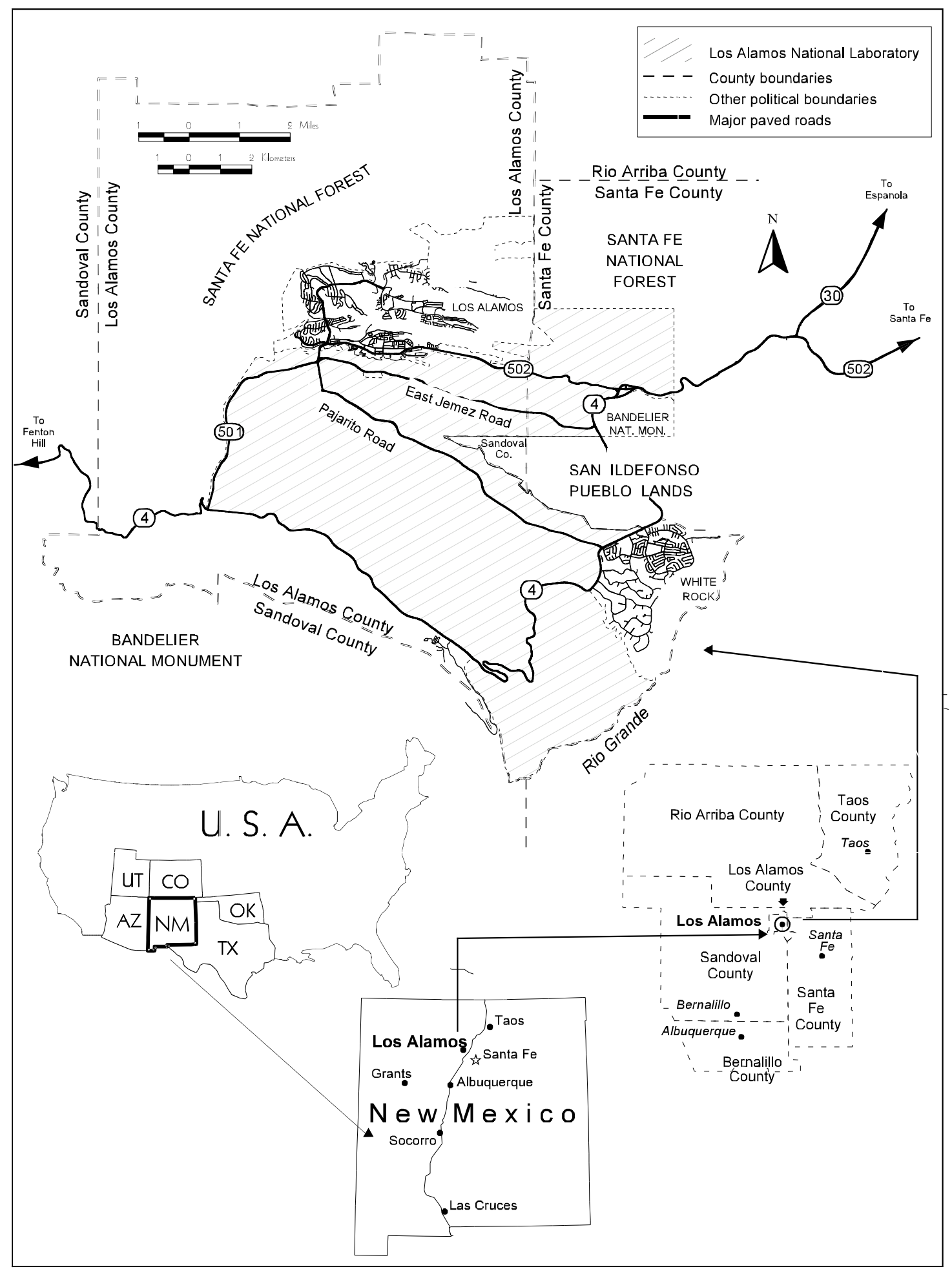

Figure 1. Location of Los Alamos National Laboratory. 
In 2000, the Cerro Grande Fire burned more than 43,000 acres (17,400 ha) and significantly altered the soils, vegetation, and surface hydrology throughout the region (BAER 2000). The high heat of the fire altered surface soil structure and created a hydrophobic layer that resisted water infiltration. Loss of effective ground cover (vegetation and litter) increases soil erosion and runoff during storms. Increased runoff and associated gully and rill erosion created dramatic increases in flood discharge that caused geomorphic changes in stream channels such as widening, changes in substrate size, and increased sediment loads. Watersheds affected by the fire in our study area include Los Alamos Canyon (33\% burned), Sandia Canyon (11\% burned), Pajarito Canyon including Starmer's Gulch (62\% burned), and Water Canyon (52\% burned). 


\section{METHODS}

LANL staff performed habitat assessments, benthic macroinvertebrate sampling, and pebble counts at five permanent sampling locations twice per year, usually in early summer and fall. The five permanent sampling locations are Los Alamos Canyon upstream of the reservoir; Sandia Canyon upstream and downstream of the wetlands; Starmer's Gulch just upstream of its confluence with Pajarito Canyon; and Pajarito Canyon approximately 1 mile $(1.6 \mathrm{~km})$ downstream of the confluence with Starmer's Gulch. In the past we have reported data from Water Canyon (Figure 2) approximately 3 miles $(5 \mathrm{~km})$ upstream of Highway 4. Flow at Water Canyon was intermittent and no macroinvertebrate samples were collected during 2002 so this site has been omitted from this report. Due to fire restrictions and other factors beyond the control of ENV-WQH, the spring sampling visits in 2001 were delayed until July, and Spring 2002 sampling was conducted only at the two Sandia Canyon locations.

LANL maintains a stream gaging network to monitor stream flow levels and to collect runoff samples for various regulatory and stewardship programs. Most gages at LANL are equipped with complete record collecting equipment that record discharge in 5minute increments. Daily mean flow and annual mean discharge in cubic feet per second (cfs) are calculated for each station. Data from LANL gage stations located near our sampling sites were used to determine mean daily discharge in cfs.

\subsection{Study Locations}

\subsubsection{Upper Los Alamos Canyon}

The Los Alamos Canyon watershed drains 8,834 acres (3,575 ha), with its headwaters located in the Sierra de los Valles. The canyon drains into White Rock Canyon of the Rio Grande, near Otowi bridge. The upper Los Alamos Canyon sampling site is located at an elevation of 7,729 $\mathrm{ft}(2,356 \mathrm{~m})$, approximately $750 \mathrm{ft}(228 \mathrm{~m})$ upstream of the Los Alamos Reservoir on U.S. Department of Agriculture (USDA) Forest Service land. The sample site was heavily impacted by the Cerro Grande Fire of 2000, when approximately $63 \%$ of the upper Los Alamos watershed was burned (BAER 2000). The site itself received a moderate-burn severity and is surrounded by steep slopes that received a highburn severity. The south side of the site has one large gully flowing into it from a steep slope, which has contributed large amounts of fine and course sediment to the stream. The north bank is somewhat buffered by an abandoned road. The riparian vegetation of the site was greatly impacted by the fire. Most of the overstory trees were killed, and the riparian area is being re-colonized by aspen clones, grasses, and forbs.

\subsubsection{Upper Sandia Canyon}

The Sandia Canyon watershed drains 3,588 acres (1,452 ha) and is located entirely on LANL property near Technical Area (TA) 3 and Diamond Drive. The watershed for upper Sandia Canyon is essentially 100\% developed, consisting of industrial buildings and parking lots. The upper Sandia sampling site is located at an elevation of 7,293 ft $(2,223 \mathrm{~m})$, approximately $2,500 \mathrm{ft}(762 \mathrm{~m})$ south of Diamond Drive. The site is in a tuff canyon with approximately $30 \mathrm{ft}(9.1 \mathrm{~m})$ of floodplain. A road crossing with fill-bridge and culvert is located approximately $80 \mathrm{ft}(24 \mathrm{~m})$ downstream of the sampling reach. This site was not burned in the Cerro Grande Fire. Riparian vegetation consists of mixed 
conifer overstory with shrubs such as cherry and rose, grass, and forbs. Benthic substrate consists of bedrock and gravels.

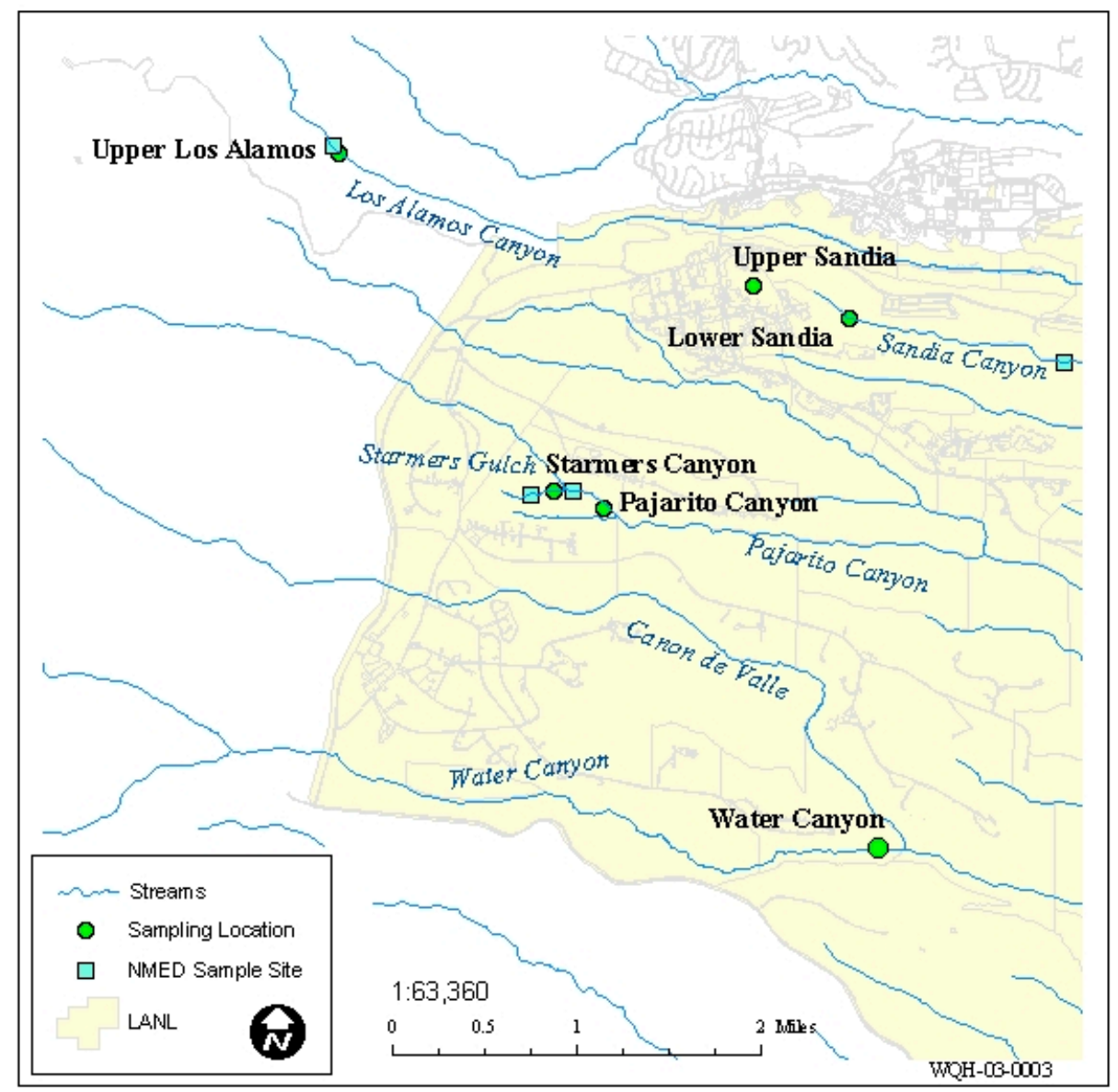

Figure 2. Location of sampling stations. With the exception of Water Canyon, geographic positioning system data were used to locate the sampling stations on the map. The location of the sampling station in Water Canyon was estimated.

\subsubsection{Lower Sandia}

The lower Sandia sampling site is located at an elevation of 7,178 $\mathrm{ft}(2,188 \mathrm{~m})$, approximately 2,625 $\mathrm{ft}(800 \mathrm{~m})$ downstream of the upper Sandia sampling site, and approximately $328 \mathrm{ft}(100 \mathrm{~m})$ downstream of the Sandia wetlands. This site has a very narrow riparian area due to large tuff boulders and bedrock outcrops that constrict the stream. Due to the confinement, the stream has a relatively high width-to-depth ratio. This section of watershed is influenced by the same urban watershed factors as the upper Sandia locations, with the addition of the Los Alamos County Landfill on the north bank, and a head cut in the Sandia Wetlands. This site was not directly affected by the Cerro Grande Fire. Riparian vegetation consists of ponderosa pine overstory, with willows, grass, and forbs. Benthic substrate consists of bedrock and fine particles. 


\subsubsection{Starmer's Gulch}

Starmer's Gulch is a tributary to Pajarito Canyon. The watershed starts above LANL in the Sierra de los Valles and drains 1,616 acres (654 ha). The upper portion of the watershed is managed by the USDA Forest Service. The Cerro Grande Fire burned approximately $83 \%$ of the watershed (BAER 2000). The Starmer's Gulch sampling site is located at an elevation of 7,381 ft $(2,250 \mathrm{~m})$ in a $\mathrm{V}$-shaped canyon, approximately $150 \mathrm{ft}$ (45 m) upstream from the confluence of Starmer's Gulch and Pajarito Canyon.

Vegetation consists of mixed conifer on the south bank and ponderosa pine on the north. This vegetation adjacent to the stream received a light burn from the Cerro Grande Fire. Substrate in the stream consists of bedrock and large angular pieces of tuff.

\subsubsection{Pajarito Canyon}

The Pajarito Canyon watershed starts in the Sierra de los Valles and drains 8,510 acres $(3,444 \mathrm{ha})$. The upper portion of the watershed is managed by the USDA Forest Service. The Cerro Grande Fire burned $62 \%$ of the watershed (BAER 2000). The Pajarito Canyon sampling site is located at an elevation of 7,329 $\mathrm{ft}(2,234 \mathrm{~m})$ in a bedrock canyon approximately 1,600 ft $(487 \mathrm{~m})$ downstream from the junction of Starmer's Gulch and Pajarito Canyon. Vegetation consists of mixed conifer on the south bank and ponderosa pine on the north. The vegetation adjacent to the stream received a moderate burn from the Cerro Grande Fire. Substrate in the stream consists of sands and gravels. Riparian vegetation consists of mostly weeds, with little to no grass or shrubs.

\subsection{Habitat Assessments}

LANL staff evaluated stream habitats in a 330-ft $(100-\mathrm{m})$ reach using the U.S. Environmental Protection Agency (EPA) Rapid Bioassessment Protocol (RBP) Habitat Assessment field data sheet for high gradient streams (in Appendix A, pages 42-43). The EPA RBP Habitat Assessment field data sheet provides criteria for rating the following 10 habitat parameters: epifaunal substrate and cover, embeddedness, velocity/depth regime, sediment deposition, channel flow status, channel alteration, frequency of riffles, bank stability, vegetative bank protection, and riparian vegetation zone. A score of 0 to 20 is possible for each of the 10 parameters. The sum of the scores for the individual parameters provides a numerical basis for comparing the habitat conditions for LANL streams to each other. We also used a modified version of the Arizona Department of Environmental Quality's (ADEQ) site assessment protocol to provide complementary information about physical characteristics and habitat at the sites (Appendix A). Areas of overlap between the RBP and the ADEQ protocol allowed us to confirm or reconsider our ratings for certain parameters, while substantive differences between the protocols provided additional information about the sites. Scores from each site were used to make site-to-site comparisons within a single sampling period and will also be used to monitor for habitat changes at each site over time. These scores and their ratings for each parameter are also used to provide context for interpretation of the macroinvertebrate community data.

\subsection{Pebble Counts}

Pebble counts are useful for characterizing the composition of channel substrates and evaluating how the substrate composition changes over time (Bevenger and King 1995). 
This information can be used to evaluate how prone the stream reach will be to erosion, whether it is being impacted by land use changes and human activities in the watershed, and the suitability of the substrate for supporting aquatic life.

ENV-WQH personnel trained in proper "zigzag" pebble count procedure conducted pebble counts at LANL. The zigzag method is a modification of the Wolman (1954) pebble count procedure. The procedure is conducted by traversing a stream in a zigzag manner from bankfull to bankfull, which is defined as the level of stream flow that fills the channel to a point where any additional water will overflow onto the stream's floodplain (Rosgen 1996). At each pace the data collector picks up, without looking, the first piece of substrate that is touched at the tip of their boot. The piece of substrate is measured on its median axis and recorded on the field data sheet (Appendix A). This procedure is continued until 100 pebbles have been selected and measured over the sample reach of stream.

Statistical analysis of pebble count data was conducted using the size-class pebble count analysis tool (v1) developed by John Potyondy and Kristin Bunte of the Stream Systems Technology Center, Rocky Mountain Research Station, USDA Forest Service. The sizeclass pebble count analysis tool performs statistical analysis using contingency tables and the Pearson chi-squared statistic. Pebble count data were analyzed to determine if there were significant differences between data collected in 2001 and 2002. For each of the five sampling locations, the Summer and Fall 2002 data were compared to the Summer and Fall 2001 data sets (our reference data sets) to evaluate if $p$ values for percent fines $(<2 \mathrm{~mm})$ were significantly different using a Type 1 error of alpha $=0.05$. D50 $\left(50^{\text {th }}\right.$ cumulative percentile for particle size) values were analyzed to determine if there were changes in the median particle size of each reach.

\subsection{Benthic Macroinvertebrates}

Benthic macroinvertebrates were collected with a Hess sampler $\left(0.086 \mathrm{~m}^{2}\right)$ with a $500-$ $\mu \mathrm{m}$ mesh (Figure 3). The Hess sample was collected only if the water velocity and depth (approximately $6 \mathrm{~cm}$ ) were sufficient to allow the sample to flow through the net ${ }^{1}$. Samples were collected by pushing the sampler firmly into the streambed with the net trailing downstream and disturbing the substrate within the perimeter of the sampler to dislodge the macroinvertebrates and allow the stream current to carry the specimens into the collection net. Large pieces of substrate $(>5 \mathrm{~cm})$ were brushed gently with a nylon brush and visually inspected to ensure that all of the macroinvertebrates had been dislodged. The samples were then transferred to a bucket with water and fine substrates were manually disturbed to suspend the macroinvertebrates. The samples were then strained in a \#35 sieve, transferred into a plastic sample jar, and preserved in $95 \%$ ethanol. Three replicates were collected at each sampling station for a total area of $2.7 \mathrm{ft}^{2}$ $\left(0.258 \mathrm{~m}^{2}\right)$ sampled. Samples from 2001 and 2002 were submitted to a qualified taxonomist (Gerald Z. Jacobi, Ph.D.) and identified to the lowest practicable taxonomic level. The samples were sorted completely.

\footnotetext{
${ }^{1}$ Fall 2002 flow at Pajarito Canyon and Starmer's Gulch was insufficient to collect macroinvertebrates with the Hess sampler.
} 


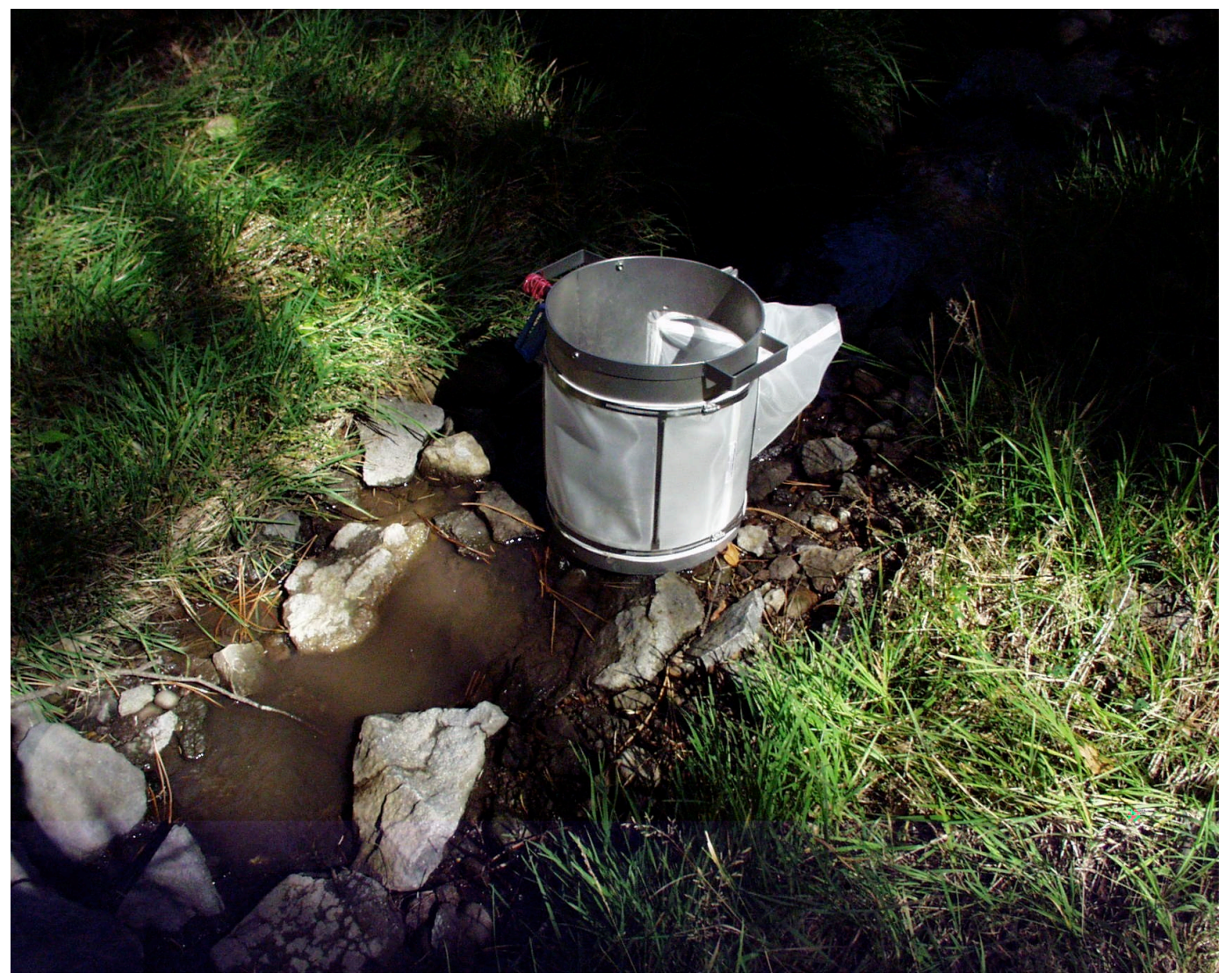

Figure 3. Starmer's Gulch, October 2002, showing Hess sampler used by LANL for collecting benthic macroinvertebrate samples. Note water depth was insufficient for sampling.

LANL staff entered macroinvertebrate sample data into the Ecological Data Application System (Tetra Tech 2003) aquatics database for analysis. In addition to the data from the 2001 and 2002 sampling periods, we also used data collected by the NMED from Pajarito Canyon and Starmer's Gulch in 1994 (Ford-Schmid 1996), from upper Los Alamos Canyon in 1997, and from lower Sandia Canyon in 1996 (NMED, unpublished data). This sample data is presented in Appendix B. We selected these data sets because sampling locations (see Figure 2) and methods were comparable. The NMED collects three replicates using a modified Hess sampler (Jacobi 1978, cited in Ford-Schmid 1996) with a $500-\mu \mathrm{m}$ mesh. The modified Hess samples an area of $0.63 \mathrm{ft}^{2}\left(0.059 \mathrm{~m}^{2}\right)$, slightly less area than a Hess sampler (for a three-replicate sample, the difference in the area sampled is $82 \mathrm{~cm}^{2}$ ). The sampling technique is the same for the two samplers. The NMED macroinvertebrate samples were also identified by Dr. Jacobi, using the same level of taxonomic resolution.

The calculation of benthic macroinvertebrate metrics requires information about specific taxa attributes that provide the inputs for each metric. We referred to Merritt and Cummins (1996) to populate the database with functional and life cycle characteristics such as feeding groups, habit, and habitat for the taxa that were represented in samples 
collected at LANL in 2001 and 2002 and by the NMED in 1996 and 1997. We also entered pollution tolerance values for each taxon. When available, we used tolerance values developed by Wisseman for western streams (Wisseman 1996; see for tolerance values). For taxa not included in the Wisseman (1996) list, we consulted Barbour et al. (1999), which includes tolerance values for five regions of the U.S. There are no tolerance values for the Southwest listed in Barbour et al. (1999), and moreover, many taxa included in Barbour et al. (1999) do not have tolerance values listed for all regions. We used the following order of preference for selecting tolerance values for our taxa: Northwest, Upper Midwest, Midwest, Southeast, and Mid-Atlantic. The source for each tolerance value was noted in the database, and tolerance values will be updated as they become available for this region. Taxa attributes and tolerance values are presented in Appendix C.

Metric selection was based on Jacobi et al. (2004), which analyzed a large historical aquatic macroinvertebrate data set to arrive at a preliminary set of statistically validated metrics for New Mexico. Jacobi et al. (2004) and Jacobi (personal communication) recommend three different multi-metric Stream Condition Indices (SCIs) depending on watershed size and elevation (high elevation-small catchment, low elevation-large catchment, low elevation-small catchment). With the exception of the site in upper Los Alamos Canyon, LANL sampling locations are classified per Jacobi et al. (2004) as low elevation-small catchment sites. Upper Los Alamos is classified as a high elevation-small catchment site (Appendix D). The low elevation-small catchment SCI is further subdivided by sample season (Table 1), so that one of the metrics is omitted from summer samples.

To arrive at an overall multi-metric score for a site, individual metric scores within each set of metrics were standardized to a 0 to 100 point scale, and the average metric score was then calculated. These overall scores were then calibrated based on season and assigned a condition rating (comparable to reference, slightly impaired, moderately impaired, or severely impaired). Seasonal thresholds used for assigning condition ratings are presented in Table 2 . 
Table 1. Metrics used for evaluation of LANL sites and their hypothesized response to increases in environmental perturbation.

\begin{tabular}{|c|c|c|c|c|}
\hline \multirow[b]{2}{*}{ Metric } & \multirow[b]{2}{*}{ Definition } & \multirow[b]{2}{*}{$\begin{array}{l}\text { Hypothesized } \\
\text { response to } \\
\text { environmental } \\
\text { perturbation }\end{array}$} & \multicolumn{2}{|c|}{ Recommended metrics by season } \\
\hline & & & $\begin{array}{c}\text { Low elevation- } \\
\text { small } \\
\text { catchment } \\
\text { samples } \\
\end{array}$ & $\begin{array}{c}\text { High elevation- } \\
\text { small } \\
\text { catchment } \\
\text { samples } \\
\end{array}$ \\
\hline \multicolumn{5}{|l|}{ Richness } \\
\hline Total \# taxa & Measures overall variety of the macroinvertebrate assemblage & decrease & & all seasons \\
\hline \# Ephemeroptera taxa & Number of taxa in the insect order Ephemeroptera (mayflies) & decrease & & all seasons \\
\hline \# Diptera taxa & Number of taxa in the insect order Diptera (true flies) & decrease & & all seasons \\
\hline \# Plecoptera taxa & Number of taxa in the insect order Plecoptera (stoneflies) & decrease & & all seasons \\
\hline \multicolumn{5}{|l|}{ Composition } \\
\hline Shannon Diversity Index & $\begin{array}{l}\text { Incorporates richness and evenness in a measure of general diversity and } \\
\text { composition }\end{array}$ & decrease & & all seasons \\
\hline Pielou's Evenness Index & Measures distribution of individuals among taxa & decrease & & all seasons \\
\hline$\%$ Plecoptera & Percent of individuals in the insect order Plecoptera (stoneflies) & decrease & & all seasons \\
\hline \multicolumn{5}{|l|}{ Tolerance } \\
\hline Hydrophsychidae to EPT \% & $\begin{array}{l}\text { Percent pollution-tolerant caddisflies of all Ephemeroptera (mayflies), } \\
\text { Plecoptera (stoneflies) and Trichoptera (caddisflies) }\end{array}$ & increase & all seasons & \\
\hline \# intolerant taxa & $\begin{array}{l}\text { Taxa richness of those organisms considered to be sensitive to } \\
\text { perturbation (tolerance values } 0 \text { to } 3 \text { ) }\end{array}$ & decrease & all seasons & all seasons \\
\hline \multicolumn{5}{|l|}{ Feeding } \\
\hline$\%$ scraper individuals & Percent of the macroinvertebrates that scrape upon periphyton & decrease & all seasons & \\
\hline$\%$ shredder individuals & Percent of individuals from the shredder functional feeding group & decrease & all seasons & all seasons \\
\hline \# shredder taxa & Number of taxa from the shredder functional feeding group & decrease & & all seasons \\
\hline \multicolumn{5}{|l|}{ Habit } \\
\hline$\%$ sprawler individuals & $\begin{array}{l}\text { Percent of individuals having fixed retreats or adaptations for attachment } \\
\text { to surfaces in flowing water }\end{array}$ & & spring, fall & all seasons \\
\hline \# sprawler taxa & $\begin{array}{l}\text { Number of taxa having fixed retreats or adaptations for attachment to } \\
\text { surfaces in flowing water }\end{array}$ & decrease & & all seasons \\
\hline \# swimmer taxa & $\begin{array}{l}\text { Number of taxa adapted for "fishlike" swimming in lotic or lentic } \\
\text { habitats }\end{array}$ & decrease & & all seasons \\
\hline
\end{tabular}


Table 2. Seasonal thresholds for SCls. Sites that score at or above the $25^{\text {th }}$ percentile for reference sites are assigned a rating of "comparable to reference." Sites that score lower than the $25^{\text {th }}$ percentile for reference sites are assigned a rating indicating varying degrees of impairment.

Low Elevation-Small Catchment Index Ranges

High Elevation-Small Catchment Index Ranges

\begin{tabular}{|c|c|c|c|c|c|c|c|}
\hline Rating & $\begin{array}{l}\text { Reference Condition } \\
\text { Index Percentile }\end{array}$ & Spring & Summer & Fall & Spring & Summer & Fall \\
\hline Comparable to Reference & $\geq 25$ & $\geq 33.00$ & $\geq 42.81$ & $\geq 33.00$ & $\geq 53.44$ & $\geq 53.44$ & $\geq 56.52$ \\
\hline Slightly Impaired & $16-24$ & $26.19-32.99$ & $31.34-42.80$ & $26.19-32.99$ & $47.63-53.43$ & $47.63-53.43$ & $50.34-56.51$ \\
\hline Moderately Impaired & $6-15$ & $18.61-26.18$ & $18.59-31.33$ & $18.61-26.18$ & $41.18-47.62$ & $41.18-47.62$ & $43.47-50.33$ \\
\hline Severely Impaired & $\leq 6$ & $<18.61$ & $<18.59$ & $<18.61$ & $<41.18$ & $<41.18$ & $<43.47$ \\
\hline
\end{tabular}




\section{RESULTS}

\subsection{Stream Flow}

\subsubsection{Upper Los Alamos Canyon}

LANL does not have a gage station located near the upper Los Alamos sampling location, but flow was visually estimated at less than $1 \mathrm{cfs}$ during stream monitoring. Stream flow at this location is considered perennial (stream flow every day of the year). The nearest LANL gage station (E026) is located in Los Alamos Canyon approximately 3 miles $(4.8 \mathrm{~km})$ below the reservoir and near the skate rink. Stream flow is influenced by releases from the reservoir and is not a good indication of flow at our monitoring location.

\subsubsection{Upper Sandia Canyon}

Stream flow at the upper Sandia Canyon sampling location is considered to be perennial (stream flow every day of the year) and is made up almost entirely of treated wastewater from three sources. Discharge from the TA-3 power plant makes up the majority of the flow, with the remainder coming from two cooling towers also located in TA-3. Outflow from the three sources was visually estimated at $0.5 \mathrm{cfs}$, which closely matched flow recorded at station E123 downstream. LANL gage station E121 is located upstream of the monitoring location, however, the gage station is relatively new and mean flow was not available at the time of sampling.

\subsubsection{Lower Sandia Canyon}

Stream flow at the lower Sandia Canyon sampling location is considered to be perennial. Stream flow at this location consists of effluent. LANL gage station E123 is located upstream of the monitoring location. Mean annual discharge at gage E123 was $0.49 \mathrm{cfs}$ during the 2002 water year (Oct. 01 to Sept. 02) (Shaull et al. 2002).

\subsubsection{Starmer's Gulch}

Stream flow at the Starmer's Gulch site is considered to be perennial, and is the result of spring flow approximately $0.25 \mathrm{mi}(0.4 \mathrm{~km})$ upstream of the confluence with Pajarito Canyon. LANL gage station E242 is located downstream of the monitoring location. Mean annual discharge at gage E242 was 0.02 cfs during the 2002 water year (Oct. 01 to Sept. 02) (Shaull et al. 2002). The daily mean discharge was 0.01 or less for 115 days during the 2002 water year.

\subsubsection{Pajarito Canyon}

Stream flow at the Pajarito Canyon monitoring site is intermittent (flow absent on some days of the year). LANL gage station E241 is located upstream of the Pajarito Canyon monitoring site, the station was installed in 2001. Mean annual discharge at gage E242 was 0.25 cfs during the 2002 water year (Oct. 01 to Sept. 02) (Shaull et al. 2002). Station E242 had a daily mean discharge of zero $(0 \mathrm{cfs})$ for 125 days during the 2002 water year. 


\subsection{Habitat Assessment}

Habitat assessment scores for all sites are summarized in Table 3, with descriptions of habitat characteristics below. The summer of 2002 was very dry with high fire danger. Because of these conditions and personnel changes, Summer 2002 data were only collected at the two Sandia Canyon locations. Habitat assessment data were collected at all locations during Fall 2002.

Table 3. Habitat assessment scores for biological monitoring locations at LANL.

\begin{tabular}{llllll}
\hline \hline Date & $\begin{array}{l}\text { Upper Los } \\
\text { Alamos } \\
\text { Canyon }\end{array}$ & $\begin{array}{l}\text { Upper Sandia } \\
\text { Canyon }\end{array}$ & $\begin{array}{l}\text { Lower Sandia } \\
\text { Canyon }\end{array}$ & $\begin{array}{l}\text { Starmer's } \\
\text { Gulch }\end{array}$ & $\begin{array}{l}\text { Pajarito } \\
\text { Canyon }\end{array}$ \\
\hline Summer 2001 & $53 / 200$ & $166 / 200$ & $155 / 200$ & $164 / 200$ & $155 / 200$ \\
Fall 2001 & $53 / 200$ & $166 / 200$ & $155 / 200$ & $164 / 200$ & $155 / 200$ \\
Spring 2002 & No Data & $166 / 200$ & $155 / 200$ & No Data & No Data \\
Fall 2002 & $53 / 200$ & $166 / 200$ & $169 / 200$ & $147 / 200$ & $114 / 200$ \\
\hline
\end{tabular}

\subsubsection{Upper Los Alamos Canyon}

The habitat rating at the Los Alamos Canyon site was low for the fall sampling periods. The habitat rating did not change from 2001 to 2002. Los Alamos Canyon had the lowest habitat scores of all the sampling locations. With the exception of high scores for parameters evaluating the extent of channel alteration and human impacts in the riparian zone, and a marginal score for channel flow status, the site scored poorly on all other habitat parameters such as cover, emdeddedness, velocity/depth regime, and sediment deposition.

\subsubsection{Upper Sandia Canyon}

The habitat rating for this reach did not change from 2001. The overall site rating from the habitat assessment was higher for all sampling periods at the upper Sandia Canyon location than the other five locations. The site scored high in all habitat parameters.

\subsubsection{Lower Sandia Canyon}

The overall site rating for lower Sandia Canyon remained high. The habitat score remained the same between 2001 and Summer 2002, but increased in Fall 2002. Similar to the site at upper Sandia, this site scored lowest for parameters related to instream habitats and highest for parameters related to streambank stability and channel morphology. Habitat parameters for epifaunal cover, channel flow, and bank stability increased from Summer to Fall 2002 and led to the increased habitat rating.

\subsubsection{Starmer's Gulch}

The habitat rating score decreased from Summer and Fall 2001 to Fall 2002 at Starmer's Gulch. The Starmer's Gulch site scored lower than the Sandia sites, but higher than the Los Alamos Canyon and Pajarito Canyon sites. The site scored poorly on the parameters rating cover, velocity/depth regime, sediment deposition, and channel flow status. Bank stability and riparian vegetation scored high. In Fall 2002, low flow contributed to the lower habitat rating score. 


\subsubsection{Pajarito Canyon}

The habitat rating scores decreased from Fall 2001 to Fall 2002. The site ranked lower than Sandia Canyon and Starmer's Gulch, but higher than Los Alamos Canyon. The habitat score for this site was lowered due to very low flow conditions. The site scored lowest for parameters related to instream measurements such as instream habitat, velocity/depth regime, sediment deposition, and channel flow status. Parameters ranking high were related to stream bank stability and riparian vegetation.

\subsection{Pebble Counts}

\subsubsection{Upper Los Alamos Canyon}

Pebble counts were conducted at upper Los Alamos Canyon in July 2001, October 2001, and September 2002. The distribution of size class percentages was similar between July 2001 and September 2002, with a shift from gravel-dominated size classes to a mix of cobble and gravel in October 2001 (Figure 4). Percent fines $(<2 \mathrm{~mm})$ decreased significantly between Fall 2001 and Fall 2002 (22\% to 7\%, p < 0.005). The D50 increased from medium gravel in Summer 2001 (14 mm) to coarse gravel in Fall 2001 $(26 \mathrm{~mm})$ and then decreased to medium gravel in Fall $2002(14 \mathrm{~mm})$.

\subsubsection{Upper Sandia Canyon}

Pebble counts were conducted during July and October of 2001 and May and October of 2002. Substrate at the upper Sandia site is dominated by gravel and sand size classes (Figure 5). There were no significant differences in percent fines between Summer 2001 and Summer $2002(\mathrm{p}=0.14)$. Fall 2002 data are suspect due to observed data collection errors and were not statistically compared to Fall 2001, but are included in Figure 5 for visual comparison. The D50 remained in the coarse gravel size class in all sampling periods except Fall 2002, which had a D50 in the medium gravel size class.

\subsubsection{Lower Sandia Canyon}

Pebble counts were conducted during July and October of 2001 and May and October of 2002. Substrate at the lower Sandia Canyon site is dominated by bedrock and fines (Figure 6). The distribution of size class percentages was similar over the sampling dates. There were no significant differences in percent fines between Summer 2001 and Summer $2002(p=0.16)$ or Fall 2001 and Fall $2002(p=0.32)$. The D50 remained in the coarse gravel size class during Summer $2001(28 \mathrm{~mm})$ and $2002(23 \mathrm{~mm})$ and Fall 2001 $(30 \mathrm{~mm})$, but increased to very coarse gravel in Fall $2002(46 \mathrm{~mm})$.

\subsubsection{Starmer's Gulch}

Pebble counts were conducted during July and November of 2001 and in October of 2002. Substrate at this site tends to be distributed across size classes but is slightly dominated by silt (Figure 7). There were no significant differences in percent fines $(<2 \mathrm{~mm})$ between Fall 2001 and Fall $2002(\mathrm{p}=0.16)$. The D50 became larger in size, from coarse gravel in Summer $2001(24 \mathrm{~mm})$ to small cobble in Fall $2002(63 \mathrm{~mm})$. Fall 2002 D50 $(80 \mathrm{~mm})$ remained in the small cobble particle size class. 


\subsubsection{Pajarito Canyon}

Pebble counts were conducted during July and November of 2001 and October 2002. Percent fines $(<2 \mathrm{~mm})$ increased significantly from $24 \%$ in October 2001 to $59 \%$ in September $2002(\mathrm{p}<0.0001)$ (Figure 8). The D50 remained in the coarse gravel size class during Summer $2001(27 \mathrm{~mm})$ and Fall $2002(23 \mathrm{~mm})$, but decreased significantly $(\mathrm{p}<0.0001)$ to the sand size class in Fall 2002.
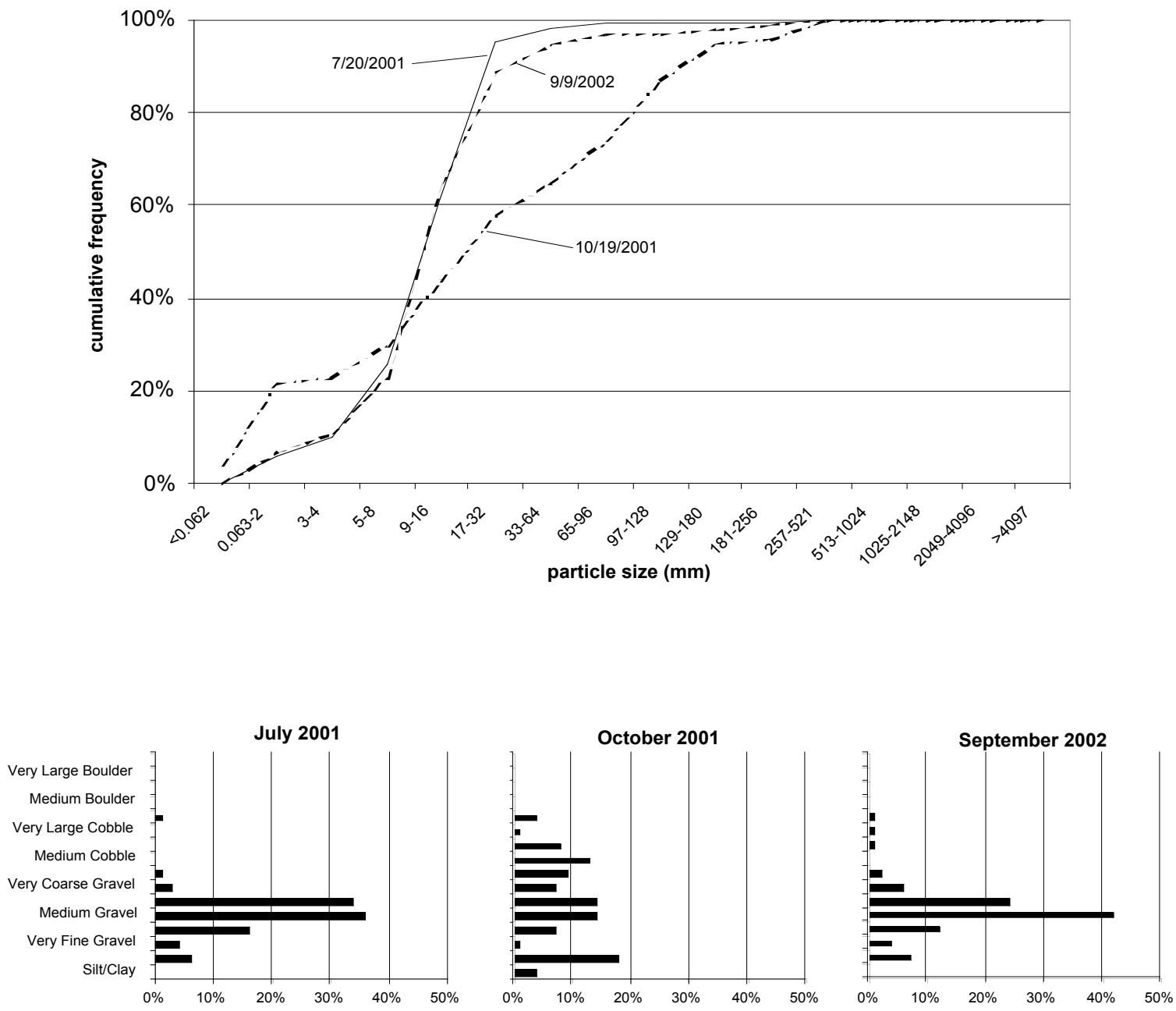

Figure 4. Cumulative percent and size distributions for benthic substrate at upper Los Alamos Canyon. 

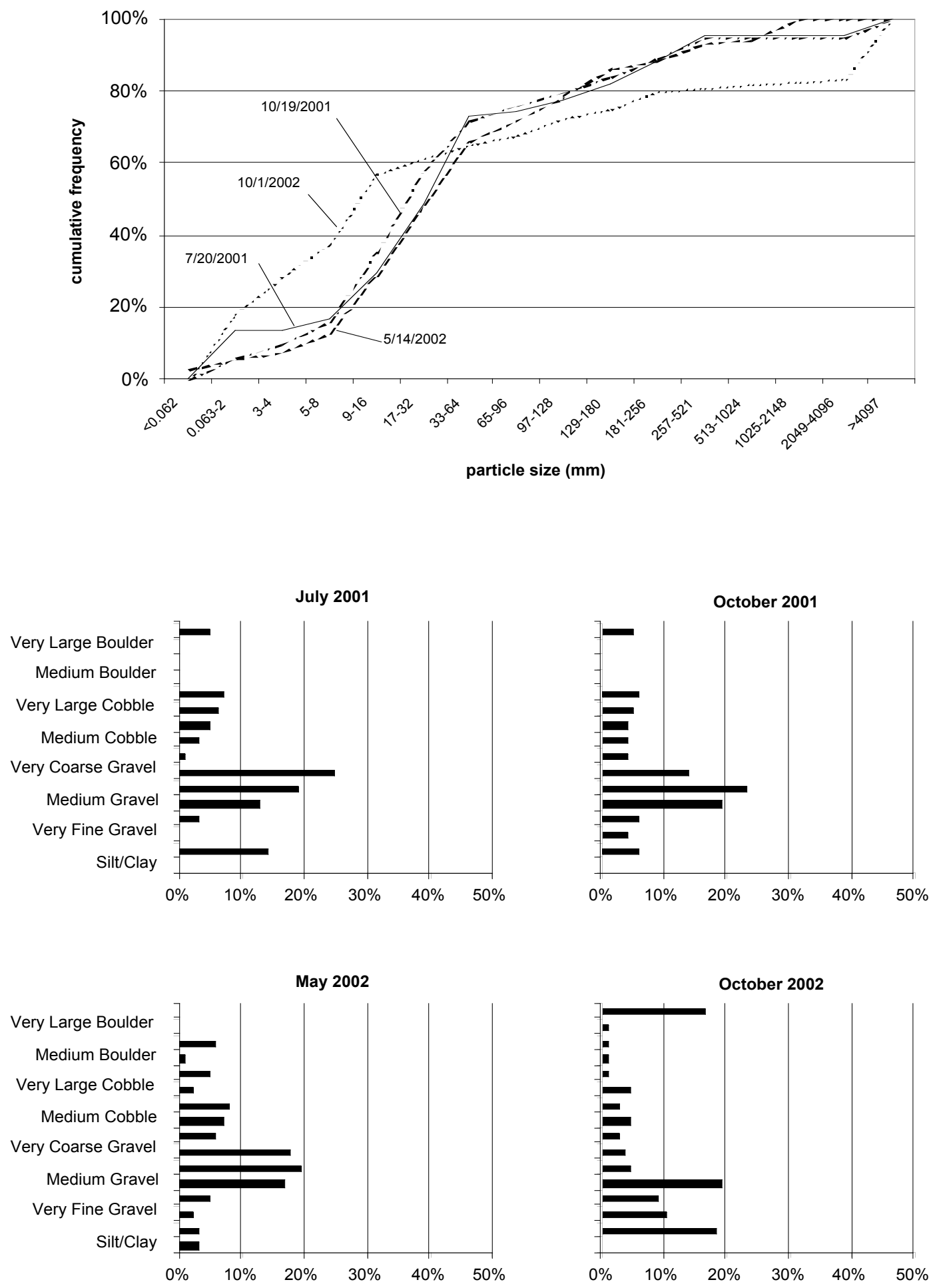

Figure 5. Cumulative percent and size distributions for benthic substrate at upper Sandia Canyon. 

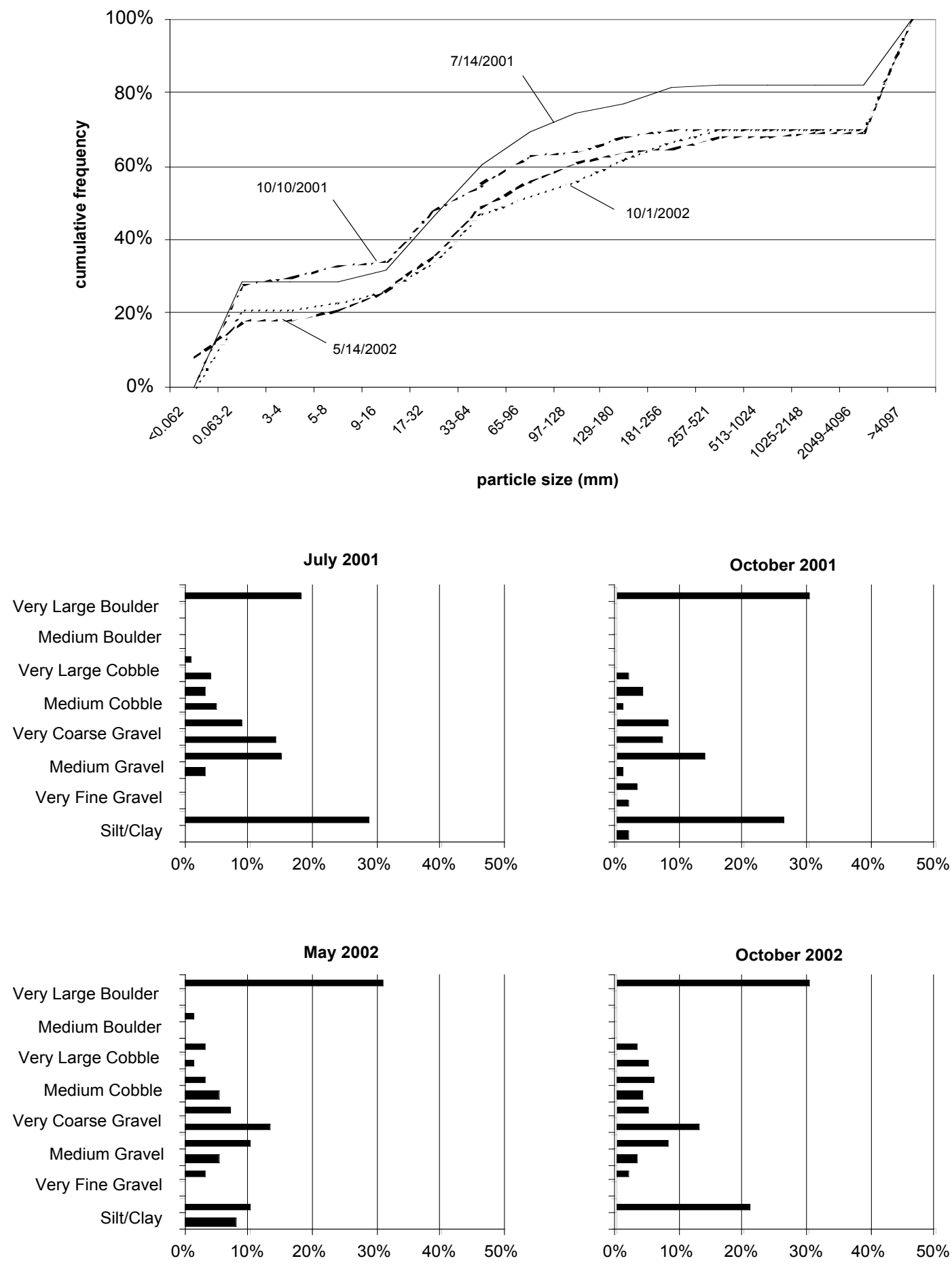

Figure 6. Cumulative percent pebble count data for lower Sandia Canyon. 

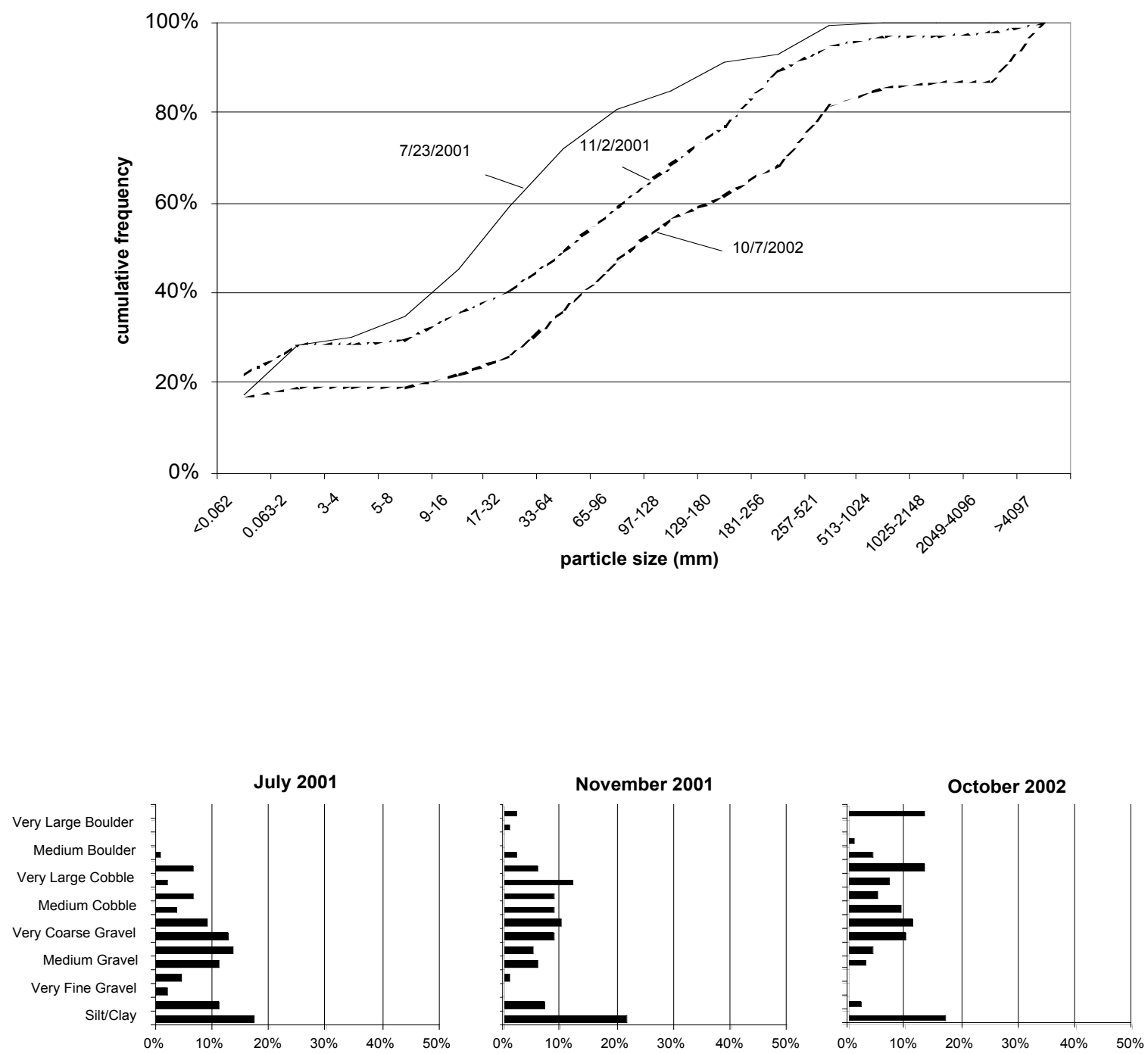

Figure 7. Cumulative percent pebble count data for Starmer's Gulch. 

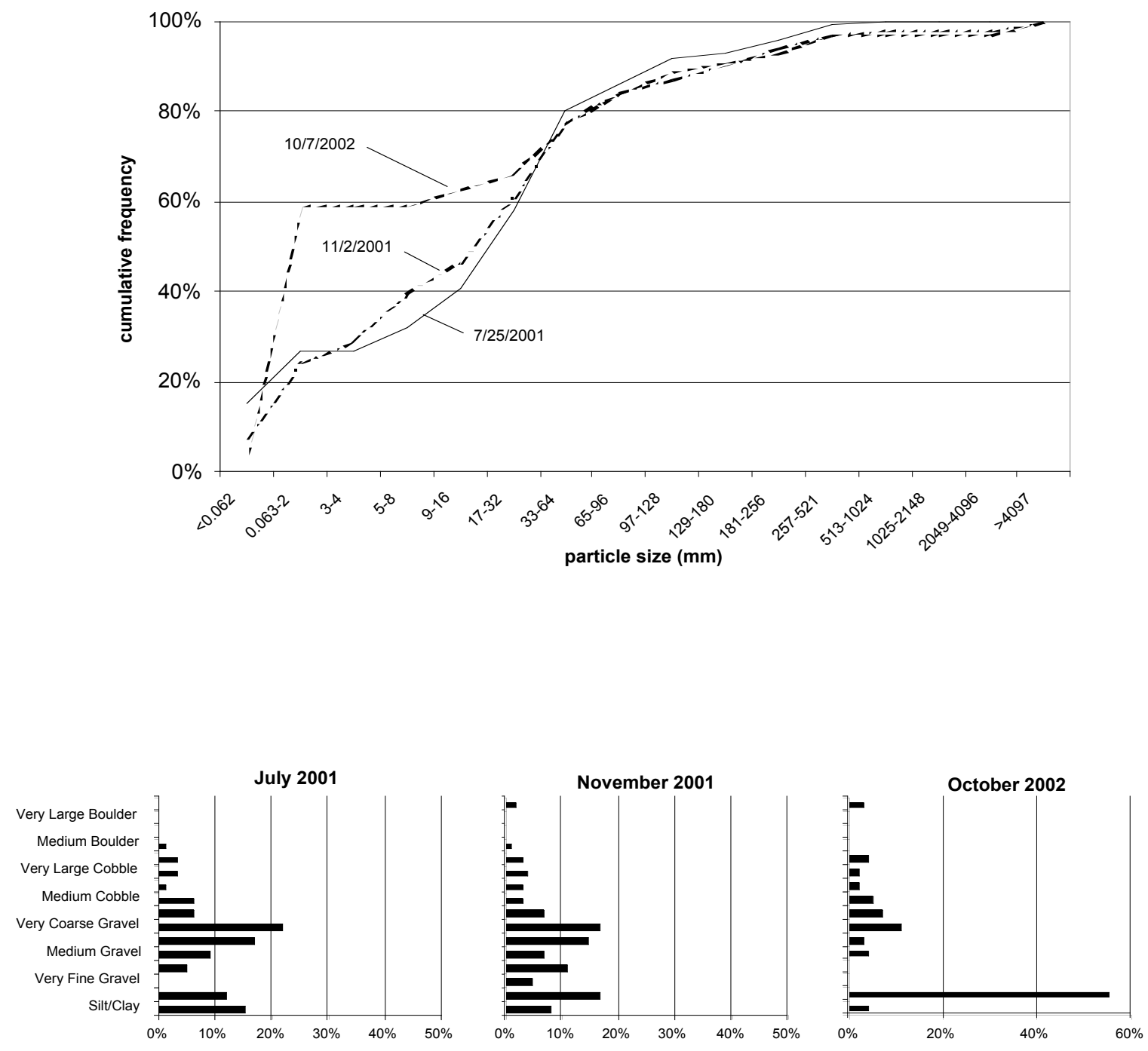

Figure 8. Cumulative percent pebble count data for Pajarito Canyon. 


\subsection{Macroinvertebrates}

SCI scores and ratings are presented in Table 4 and described below.

\subsubsection{Upper Los Alamos Canyon}

Upper Los Alamos Canyon was evaluated using the index recommended in Jacobi et al. (2004) for high elevation-small catchment sites. This SCI indicates that significant site degradation occurred between 1997 and 2001. Samples from 2001 and 2002 were rated as moderately to severely impaired compared to "comparable to reference" for the sample collected in 1997.

\subsubsection{Upper Sandia Canyon}

Upper Sandia Canyon was evaluated using the index recommended for low elevationsmall catchment sites. This site was rated as "slightly impaired" for 2001 samples (although the sample size for July 2001 was small), "moderately impaired" in the spring of 2002, and improving to "comparable to reference" in the fall of 2002.

\subsubsection{Lower Sandia Canyon}

Lower Sandia Canyon was evaluated using the index recommended for low elevationsmall catchment sites. This site was rated as "comparable to reference" for all sample periods with the exception of the July 2001 sample, which was rated as "slightly impaired."

\subsubsection{Starmer's Gulch}

Starmer's Gulch was evaluated using the index recommended for low elevation-small catchment sites and was rated as "comparable to reference" for the three sample periods.

\subsubsection{Pajarito Canyon}

Pajarito Canyon was evaluated using the index recommended for low elevation-small catchment sites. This site was rated as "comparable to reference" for the three sample periods. 
Table 4. Overall scores and ratings for macroinvertebrate communities based on NMED-recommended SCls.

\begin{tabular}{|c|c|c|c|}
\hline Site & Stream Condition Index & Score & Rating \\
\hline Upper Los Alamos & High elevation-small catchment & & \\
\hline February 1997 & & 4 & Comparable to reference \\
\hline July 2001 & & -- & Severely impaired* \\
\hline October 2001 & & 2 & Moderately impaired \\
\hline Spring 2002 & & \multicolumn{2}{|c|}{ Not sampled due to fire restrictions } \\
\hline September 2002 & & 1 & Severely impaired \\
\hline Upper Sandia & Low elevation-small catchment & & \\
\hline July 2001 & & 3 & Slightly impaired** \\
\hline October 2001 & & 3 & Slightly impaired \\
\hline May 2002 & & 2 & Moderately impaired \\
\hline October 2002 & & 4 & Comparable to reference \\
\hline Lower Sandia & Low elevation-small catchment & & \\
\hline March 1996 & & 4 & Comparable to reference \\
\hline July 2001 & & 3 & Slightly impaired \\
\hline October 2001 & & 4 & Comparable to reference \\
\hline May 2002 & & 4 & Comparable to reference \\
\hline October 2002 & & 4 & Comparable to reference \\
\hline Starmer's Gulch & Low elevation-small catchment & & \\
\hline July 1994 & & 4 & Comparable to reference \\
\hline July 2001 & & 4 & Comparable to reference \\
\hline November 2001 & & 4 & Comparable to reference \\
\hline Spring 2002 & & \multicolumn{2}{|c|}{ Not sampled due to fire restrictions } \\
\hline Fall 2002 & & \multicolumn{2}{|c|}{ Stream flow inadequate for sampling } \\
\hline Pajarito & Low elevation-small catchment & & \\
\hline July 1994 & & 4 & Comparable to reference \\
\hline July 2001 & & 4 & Comparable to reference \\
\hline November 2001 & & 4 & Comparable to reference \\
\hline Spring 2002 & & \multicolumn{2}{|c|}{ Not sampled due to fire restrictions } \\
\hline Fall 2002 & & \multicolumn{2}{|c|}{ Stream flow inadequate for sampling } \\
\hline
\end{tabular}

* rating assigned based on extirpation of benthic macroinvertebrates from site

$* *$ small sample size $(\mathrm{n}=60)$ 


\section{DISCUSSION}

The SCI ratings were consistent with the habitat scores, pebble count data, and our knowledge of particular site stressors, indicating that the SCI functioned well to evaluate site quality. Site-specific observations are discussed below.

\subsection{Upper Los Alamos Canyon}

Pre- and post-fire habitat assessments (although estimated for pre-fire conditions) and the SCI scores for upper Los Alamos Canyon indicate that the Cerro Grande Fire had a severe impact on this site in 2001 and 2002. Pebble count data were variable over the 2001-2002 sampling period, indicating instability in the stream substrate. During site visits, many rills and gullies were noted flowing from side slopes into the main channel. These features have the potential to introduce large amounts of sediment to the stream, potentially causing debris jams that could change the reach from a high gradient $(2+\%)$ channel with degradation characteristics to a low gradient $(1 \%)$ reach with aggradation characteristics. Fine sediment $(<2 \mathrm{~mm})$ also decreases the habitat available to aquatic macroinvertebrates (Furniss et al. 1991).

Precipitation events that produced small runoff events pre-fire can produce large channelaltering runoff events post-fire due to loss of ground cover and chemical and/or physical changes in the soil properties (Moody and Martin 2001). Dramatic increase in post-fire runoff in the Los Alamos watershed may be directly tied to changes in the D50 over our sampling period. On July 13, 2001, 1.17 inches of rain fell on Los Alamos watershed (Remote Automated Weather Station [RAWS] network data) seven days before our sampling period. The D50 during our July 2001 sampling period fell into the medium gravel size class (14 mm). On August 9, 2001, 1.24 inches of rain fell on the Los Alamos watershed (RAWS network data). Fall 2001 has a D50 in the coarse gravel size class (26 $\mathrm{mm})$. The only significant runoff event of 2002 in the Los Alamos watershed occurred on July 18, 2002, when 1.15 inches of rain fell (RAWS network data). There were no other significant flows between this event and our September 9 sampling period. The D50 calculated from our September 2002 data fell into the medium gravel size class $(14 \mathrm{~mm})$.

The absence of macroinvertebrates from the Summer 2001 sample is probably related to poor habitat (almost exclusively gravel) resulting from the Cerro Grande Fire. However, low abundance might also be attributed to seasonal effects such as low flow, warmer water conditions, emergence, and scouring from rain (Jacobi 9/5/2003, personal communication). A combination of seasonal and fire effects could also explain low abundance. The improvement in the SCI score during the fall of 2001 could be due to an improvement in habitat indicated by the increase in cobble size classes for that sampling period. The subsequent decline in the SCI during Fall 2002 corresponds with a return to gravel-dominated substrates.

\subsection{Upper Sandia Canyon}

The upper Sandia Canyon habitat assessments indicated that this site had the highest habitat quality of our sample locations over the four sampling periods, and the habitat has remained stable. The constant, regulated flow and lack of fire impacts helped retain the high habitat assessment score when compared to the other locations. Pebble count data 
also indicate that the substrate at this site was stable. There were no significant differences in the percent fines between the Spring 2001 and 2002 and Fall 2001 and 2002 sampling periods. The D50 has remained in the coarse gravel size class for all sampling periods. Threats to the site include a new construction project on the bench above the south bank and the Los Alamos County Landfill on the north bank. In addition, if the flow is diverted or otherwise shut off, the site will substantially change.

The combination of having the highest habitat scores among our sites with SCI rankings indicating slight to moderate impairment suggests that in spite of having regular flow, poor water quality related to the effluent-dominated flow at this site might be negatively impacting the biota at the upper Sandia site. It must be noted that without the effluent flow, there would not be perennial flow at this site and the biota at this site would be absent or respond only to ephemeral flow events. Low abundance during the summer of 2001 could have been related to season.

\subsection{Lower Sandia Canyon}

The increase in median substrate size over the four sampling periods could be related to recovery from initial fire impacts, although this increase is not statistically significant. The high SCI ratings for this site in spite of substrates dominated by fines and bedrock are probably due to the availability of coarse gravel and cobble substrates. Furthermore, water quality is likely to have improved with distance from the effluent outfall located at the head of the canyon just upstream of the upper Sandia site. The Sandia wetland, which is located between the upper and lower Sandia sites, is likely to be a major contributor to improvements in water quality for downstream areas.

\subsection{Starmer's Gulch}

The increase in substrate particle size at Starmer's Gulch from 2001 to 2002 could be related to fire impact recovery. The low flow conditions that led to a lower habitat assessment score in 2002 and precluded macroinvertebrate sampling probably also limited aquatic life at that site. The high SCI ratings for 2001 suggest that fire impacts on stream biota were minimal.

\subsection{Pajarito Canyon}

The significant decrease in median particle size between 2001 and 2002 and increase in fines at the Pajarito site are related to sediment deposition, possibly due to fire impacts. The high SCI scores in 2001 were consistent with the habitat assessments and pebble count data, but this site appears to have destabilized between 2001 and 2002. Low flow conditions in 2002 likely limited aquatic life at that site. 


\section{CONCLUSION}

The availability of the NMED's validated set of metrics for evaluating biological condition of LANL streams represents a significant advance in our understanding of Laboratory impacts on stream health. Sampling sites that experienced severe burining in the Cerro Grande Fire (Los Alamos and Pajarito Canyons) continued to show evidence of significant impact, while sites in areas that were less heavily burned showed early signs of recovery (lower Sandia and Starmer's Gulch). The aquatic macroinvertebrate community in upper Sandia Canyon appears to be limited by poor water quality.

For management purposes, it would be useful to have the ability to distinguish macroinvertebrate community response to physical habitat conditions from the community's response to water quality conditions. Based on our field observations, we believe that poor in-stream habitats and drought conditions limit the development of healthy macroinvertebrate communities. To attempt to tease out habitat versus water quality impact on aquatic communities, we are currently conducting a pilot study using artificial samplers side-by-side with the Hess sampler. Results from this study will be presented in subsequent reports.

\section{ACKNOWLEDGMENTS}

Mike Saladen, Marc Bailey, and Kevin Buckley of ENV-WQH and Lisa Henne of ENVECO collected the field data used in this paper. Mike Saladen, Marc Bailey, and Richard Meyerhoff designed the study used for this paper. Dr. Gerald Z. Jacobi advised us on sampling methods and provided information on seasonal trends in macroinvertebrate populations. 


\section{REFERENCES}

Barbour, M.T., J. Gerritsen, B.D. Snyder, and J.B. Stribling. 1999. Rapid Bioassessment Protocols for Use in Streams and Wadeable Rivers: Periphyton, Benthic Macroinvertebrates and Fish, Second Edition. EPA 841-B-99-002. U.S. Environmental Protection Agency, Office of Water. Washington, D.C.

Bevenger, G.S. and R.M. King. 1995. A Pebble Count Procedure for Assessing Watershed Cumulative Effects. RM-Rp-319. Rocky Mountain Forest and Range Experiment Station. Fort Collins, Colorado.

Buckley, K.J., L.J. Henne, M.T. Saladen, M. Bailey, and R. Meyerhoff. 2003. Evaluation of Macroinvertebrate Communities and Habitat for Selected Stream Reaches at Los Alamos National Laboratory. LANL report LA-14171-SR.

Burned Area Emergency Rehabilitation Team. 2000. Burned Area Emergency Rehabilitation Plan for Cerro Grande Fire. Interagency BAER Team.

Cairns, J. Jr., K.L. Dickson, and G. Lanza. 1973. Rapid Biological Monitoring System for Determining Aquatic Community Structure in Receiving Systems. Pages 148-163 in Biological Methods for the Assessment of Water Quality. American Society for Testing and Materials.

Chessman, B.C. 1995. Rapid Assessment of Rivers Using Macroinvertebrates: A Procedure Based on Habitat-Specific Sampling, Family Level Identification, and a Biotic Index. Australian Journal of Ecology 20:122-129.

Cummins, K.W. 1974. Structure and Function of Stream Ecosystems. BioScience 24:631-641.

Furniss, M.J., T.D. Roelofs, and C.S. Yee. 1991. Road Construction and Maintenance. Chapter 8 (p. 297-323) in W.R. Meehan (ed.): Influences of Forest and Rangeland Management on Salmonid Fishes and Their Habitats. American Fisheries Society Special Publication $19.751 \mathrm{pp}$.

Ford-Schmid, R.E. 1996. Reference Conditions for Los Alamos National Laboratory Streams Using Benthic Macroinvertebrate Assessment in Upper Pajarito Canyon. New Mexico Geological Society Guidebook, $47^{\text {th }}$ Field Conference, Jemez Mountains Region.

Gaufin, A.R. 1973. Use of Aquatic Invertebrates in the Assessment of Water Quality. Pages 96-116 in Biological Methods for the Assessment of Water Quality. American Society for Testing and Materials.

Jacobi, G.Z. 1978. An Inexpensive Circular Sampler for Collecting Benthic Macroinvertebrates in Streams. Archives Hydrobiology 83:126-131. 
Jacobi, G.Z., M.D. Jacobi, M.T. Barbour, and E.W. Leppo. 2004. A Stream Condition Index for New Mexico Wadeable Streams. Draft Report to the New Mexico Environment Department.

Merritt, R.W. and K.W. Cummins (eds.). 1996. An Introduction to the Aquatic Insects of North America, Third Edition. Kendall/Hunt Publishing Company, Dubuque, Iowa.

Moody, J.A. and D.A. Martin. 2001. Post-fire Rainfall Intensity-Peak Discharge Relations for Three Mountainous Watersheds in the Western USA. Hydrological Processes 15:2981-2993.

New Mexico Environment Department (NMED) 2003.

http://www.nmenv.state.nm.us/swqb/Monitoring+Assessment/index.html (Accessed May $28,2003)$.

Rosenberg, D.M. and V.H. Resh. 1993. Introduction to Freshwater Biomonitoring and Benthic Macroinvertebrates. Pages 1-8 in D.M. Rosenberg and V.H. Resh (eds.) Freshwater Biomonitoring and Benthic Macroinvertebrates. Chapman and Hall, New York.

Rosgen, D.L. 1996. Applied River Morphology. Wildland Hydrology. Pagosa Springs, Colorado.

Shaull, D.A., D. Ortiz, M.R. Alexander, R.P. Romero, and E.T. Riebsomer. 2002. Surface Water Data at Los Alamos National Laboratory: 2001 Water Year. LANL report LA13905-PR.

Tetra Tech. 2003. Ecological Data Application System (EDAS), version 3.3. Customized Microsoft Access database. Acquired from ftp://anon:tt-anon-ftp@ftp.tetratechffx.com/eleppo/edas.

Wisseman, R.W. 1996. Version 1.0. Unpublished ecological coding attributes for freshwater invertebrate taxa in western North America.

Wolman, M.G. 1954. A Method of Sampling Coarse River Bed Material. Transactions of the American Geophysical Union (EOS) 35:951-956. 


\section{APPENDIX A. SAMPLE FIELD DATA FORM}

\section{LANL Bioassessment Field Data Sheet}

SAMPLE LOCATION

Date: $(\mathrm{dy} / \mathrm{mo} / \mathrm{yr})$ :

Sample Time:

Stream Name:

Site Name:

Site Description

Field Crew:

Program

Program:

$-$

SITE INFORMATION

USGS 7.5' Quadrangle:

Ownership:

Watershed Name: Elev.(ft):

HUC - Reach: County:

State: Aspect:

Site Id Latitude (DMS) Site Id Longitude (DMS): Method

Watershed Area $\left(\mathrm{mi}^{2}\right)$

Most Recent Flood Event (Date; Discharge):

Designated Uses:

\section{POST SAMPLING RECOMMENDATIONS}

(Notes about flow regime, relocating site, site access, sample types, analysis parameters, etc.)

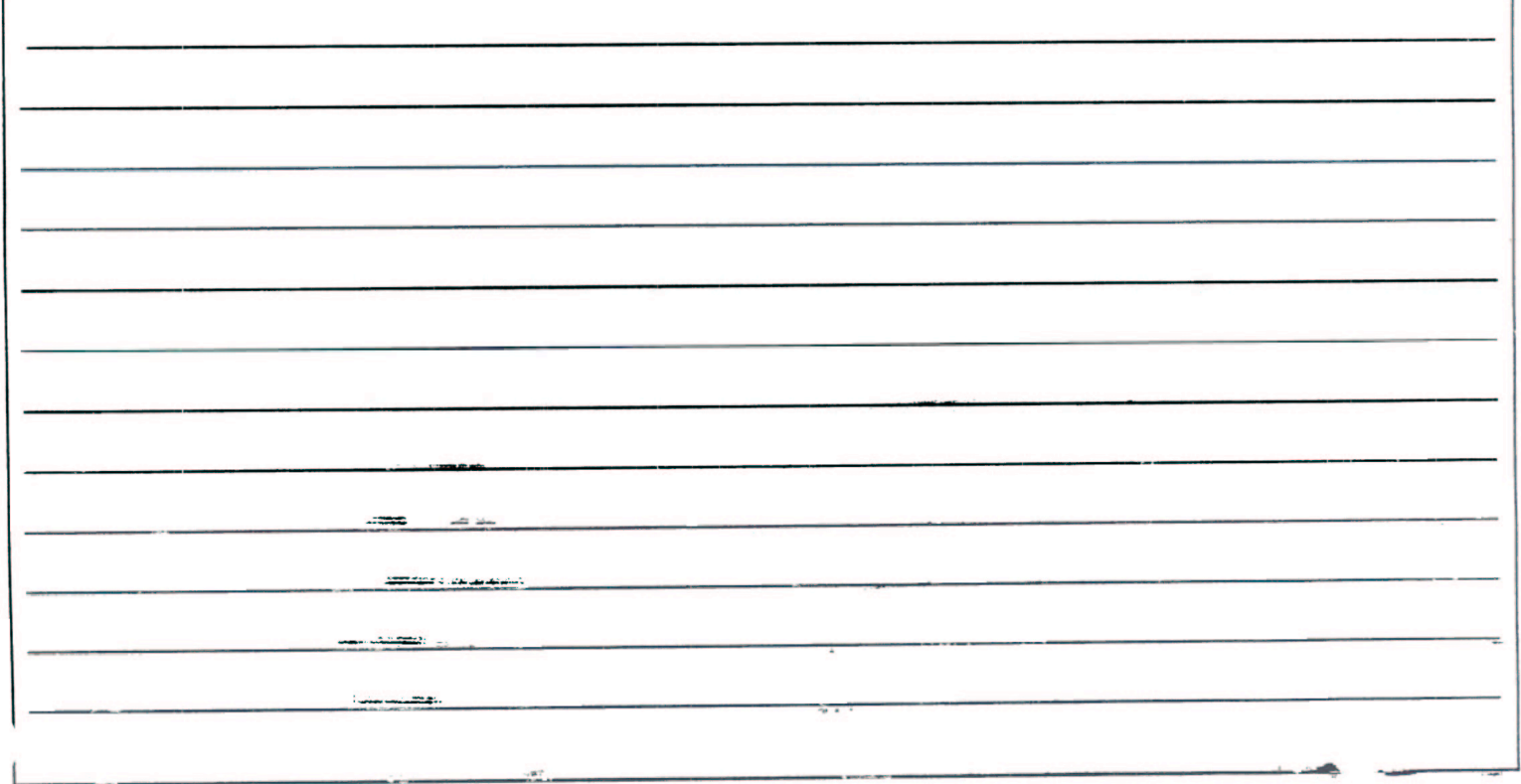


Field Observations

Trecipitation (Circle one) None Light Moderate Heavy

Previous precipitation $(24 \mathrm{hr})($ Circle one): None Light Moderate Heavy

Cloud cover $(\%)$

\section{Field Measurements}

Air $\mathrm{T}\left({ }^{\circ} \mathrm{C}\right)$ : Turbidity (NTU):

Water $\mathrm{T}\left({ }^{\circ} \mathrm{C}\right)$ : D.O. $(\mathrm{mg} / \mathrm{l})$ D.O. \% Sat: Conductivity $(\mu \mathrm{mos} / \mathrm{cm})$ : $\operatorname{TDS}(\mathrm{mg} / \mathrm{l})$ : $\mathrm{pH}$ :

QC Sample (Y/N):

\begin{tabular}{|l|l|l|l|}
\hline $\begin{array}{c}\text { Water Collection } \\
\text { Method: }\end{array}$ & Parameter Sets: & \multicolumn{2}{|c|}{ Biological Samples: } \\
\hline Composite & Inorganics & Macroinvertebrates: & Macroinvertebrates: \\
\hline Grab & Nutrients & Riffle (field split & Edge (field split \\
\hline & - Total Metals & Pool (field split & Other (field split \\
\hline & - Dissolved Metals & Algae: & Algae: \\
\hline & Bacteria & Diatoms, Riffle & Filamentous, Riffle \\
\hline & Radiochemicals & Diatoms, Pool & Filamentous, Pool \\
\hline & Parasites/Niruses & Diatoms, Artificial Substrate & Filamentous, composite \\
\hline & Other & & \\
\hline
\end{tabular}

AdDITIONAL SAMPLe Notes 


\begin{tabular}{|c|c|c|c|c|c|c|}
\hline & Distance $\mathrm{ft}$ & Width, $\mathrm{ft}$. & Depth. ft. & Area, $\mathrm{ft}^{2}$ & Velocity ft/s & Discharge cfs \\
\hline 1 & & & & & & \\
\hline 2 & & & & & & \\
\hline 3 & & & & & & \\
\hline 4 & & & & & & \\
\hline 5 & & & & & & \\
\hline 6 & & & & & & \\
\hline 7 & & & & & & \\
\hline 8 & & & & & & \\
\hline 9 & & & & & & \\
\hline 10 & & & & & & \\
\hline 11 & & & & & & \\
\hline 12 & & & & & & \\
\hline 13 & & & & & & \\
\hline 14 & & & & & & \\
\hline 15 & & & & & & \\
\hline 16 & & & & & & \\
\hline 17 & & & & & & \\
\hline 18 & & & & & & \\
\hline 19 & & & & & & \\
\hline 20 & & & - & & & \\
\hline $2 i$ & & & & & & \\
\hline 22 & & & & & & \\
\hline 23 & & & & & & \\
\hline 24 & & & & & & \\
\hline 25 & & & & & & \\
\hline 26 & & & & & & \\
\hline 27 & & & & & & \\
\hline & TOTAL $=$ & & $A V G=$ & TOTAL $=$ & AVG $=$ & TOTAL $=$ \\
\hline
\end{tabular}

FLoAT METHOD

Float distance should be 2-3 times wetted width of stream.

Float Distance, ft: $\quad$ Float Time (seconds)

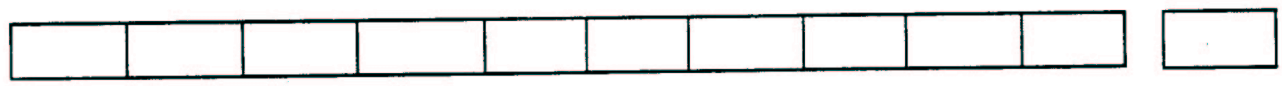

Float Distance (ft.):

Avg. Velocity:

Avg. Time(s): $\times 0.85$ Correction Factor $=$ $x$ Area $\left(\mathrm{ft}^{2}\right)$ : Avg. Velocity (ft/s) Connected Velocity (ft/s) Discharge cfs 


\section{General Site Characteristics}

Seneral Appearance in the Stream Reach (Check all that apply)

No refuse visible

Small volume refuse (e.g., cans, paper) rare

Small volume refuse common
Large volume refuse (e.g., tires, carts) rare Large volume refuse common

General Appearance of the Streambank along the Reach (Check all that apply)

No refuse visible

Small volume refuse (e.g., cans, paper) rare

Small volume refuse common

Water Appearance (Check all that apply)

$\begin{array}{lll}\text { Clear } & \text { Light brown } & \text { Reddish } \\ \text { Milky } & \text { Dark Brown } & \text { Greenish } \\ \text { Turbid } & \text { Oily Sheen } & \text { Other _ }\end{array}$

Water Odor (Check all that apply)

$\begin{array}{lll}\text { None } & \text { Chlorine } & \text { Rotten eggs } \\ \text { Sewage } & \text { Fishy } & \text { Other }\end{array}$

Appearance at Water's Edge (Check one)

No evidence of salt crusts

Numerous white crusty deposits localized

White crusty deposits rare

Banks covered with white crusty deposits

ish (Based on observation)

1. Abundant Comments:

2. Rare Comments:

3. Absent Comments:

Crayfish (Based on observation)

1. Abundant Comments:

2. Rare Comments:

3. Absent Comments:

Recent (past 2 months) flood or long term drought evidence (Check all that apply)

No recent flood evidence

Fresh debris line

Grasses laid over

Recent flood event greater than baseflow:

$<$ bankfull width

$>$ bankfull width - estimated width

\section{Flow Regime (Check one)}

Perennial stream channel. Surface water persists all year long.

Intermittent stream channel. One which flows only seasonally or sporadically. Surface sources include springs, snow melt and flows that reappear along various locations of a reach, then run subterranean (interrupted).

Subterranean stream channel. Flows parallel to and near the surface for various seasons; a subsurface flow which follows the stream bed.

Ephemeral stream channel. Flows only in response to precipitation. 
Flow Variability (Check one)

Seasonal variation in stream flow dominated primarily by snowmelt runoff. Seasonal variation in stream flow dominated primarily by stormflow runoff. Uniform stage and associated stream flow due to spring fed condition.

Regulated stream flow due to diversions, dam release, dewatering, etc.

Altered flows due to development such as urban streams, cut-over watersheds, vegetation conversions (e.g. forested to grassland) that changes flow response to precipitation events.

\section{Aquatic Plants}

\section{Filamentous Algae}

Estimated percent of filamentous algae covering stream bed throughout study reach $\%$ cover

\section{Floating Algae}

Are any detached clumps or mats of algae floating downstream?

1. Abundant Comments:

2. Rare Comments:

3. Absent Comments:

Algal Slime (not filamentous)

re the submerged rocks, bedrock, woody material in the stream coated with a layer of algal slime? May be slippery to the touch, but not readily visible.

Abundant - thick-coating Comments:

Rare - thin-coating Comments:

Absent Comments:

Percent macrophytes covering stream bed throughout the reach: $\%$ cover

Description of algae/macrophytes in reach (emergent and submergent): 
ChanNel/HABITAT Complexity

(Reach length equals 2 meander lengths or 20-30 times bankfull width of the stream) Use a minimum of $100 \mathrm{~m}$ reach to 'entify habitat types for large streams.

\begin{tabular}{|c|c|c|c|}
\hline Habitat & Number of Paces & $\%$ & \\
\hline \multicolumn{3}{|l|}{ Pool } & \\
\hline \multicolumn{4}{|l|}{ Riffle } \\
\hline Run & & & Riffle/Pool Ratio \\
\hline Total & & & \\
\hline
\end{tabular}

\section{EMBEDDEDNESS}

(Estimate the percent Embeddedness of 10 cobbles along each of three riffle transects. Select three different riffles within the reach wherever possible. Begin and end transect at edges of riffle, don't include edge particles of the wetted width. Count sand and fines as $100 \%$ embedded and bedrock and hardpan as $0 \%$ embedded. Gravel that is selected from a patch of gravel is considered $100 \%$ embedded)

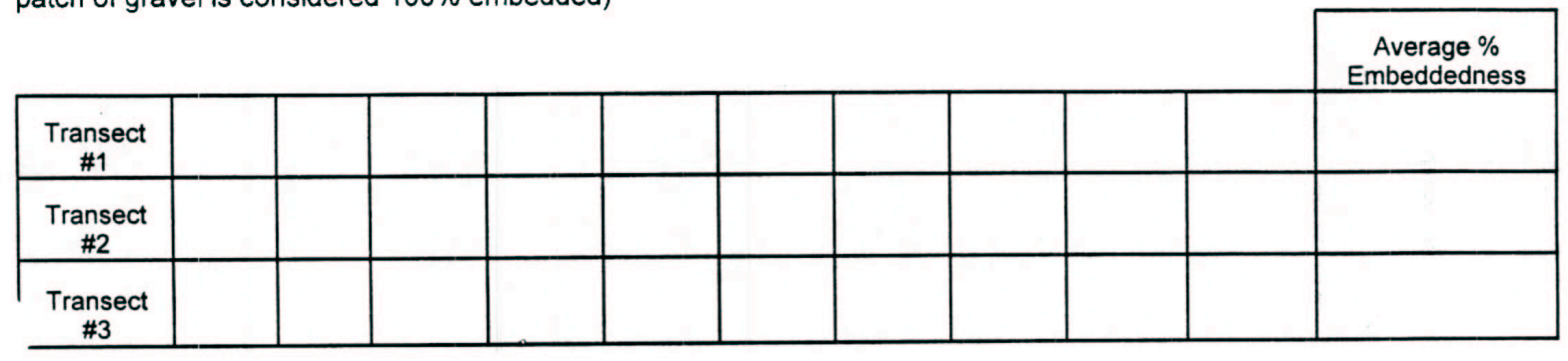

Organic Debris/Channel Blockages (in Active Channel)

Mark single most appropriate description

No organic debris or channel blockages

Infrequent debris, what's present consists of small, floatable organic debris.

Moderate frequency, mixture of small to medium size debris affects less than $10 \%$ of active channel area.

Numerous debris mixture of medium to large sizes - affecting up to $30 \%$ of the area of the active channel.

Debris dams of predominantly large material affecting over $30 \%$ to $50 \%$ the channel area and often occupying the total width of the active channel.
Extensive, large debris dams either continuous or influencing over $50 \%$ of channel area. Forces water onto flood plain even with moderate flows. Generally presents a fish migration blockage.

Beaver dams. Few and/or infrequent. Spacing allows for normal stream/flow conditions between dams.

Beaver dams - Frequent. Back water occurs between dams - stream flow velocities reduced between dams.

Beaver dams - abandoned where numerous dams have filled in with sediment and are causing channel adjustments of lateral migration, avulsion, and degradation etc.

Man made structures - diversion dams, low dams, controlled by-pass channels, baffled bed configuration with gabions, etc. 
SITE MAP SKETCH: (Include location of riffles, pools, runs, snags, submerged logs, undercut banks, areas of stable - obble habitat, point bars, mid-channel or side bars, areas with cut or eroding banks, location and types of riparian zgetation, etc.)

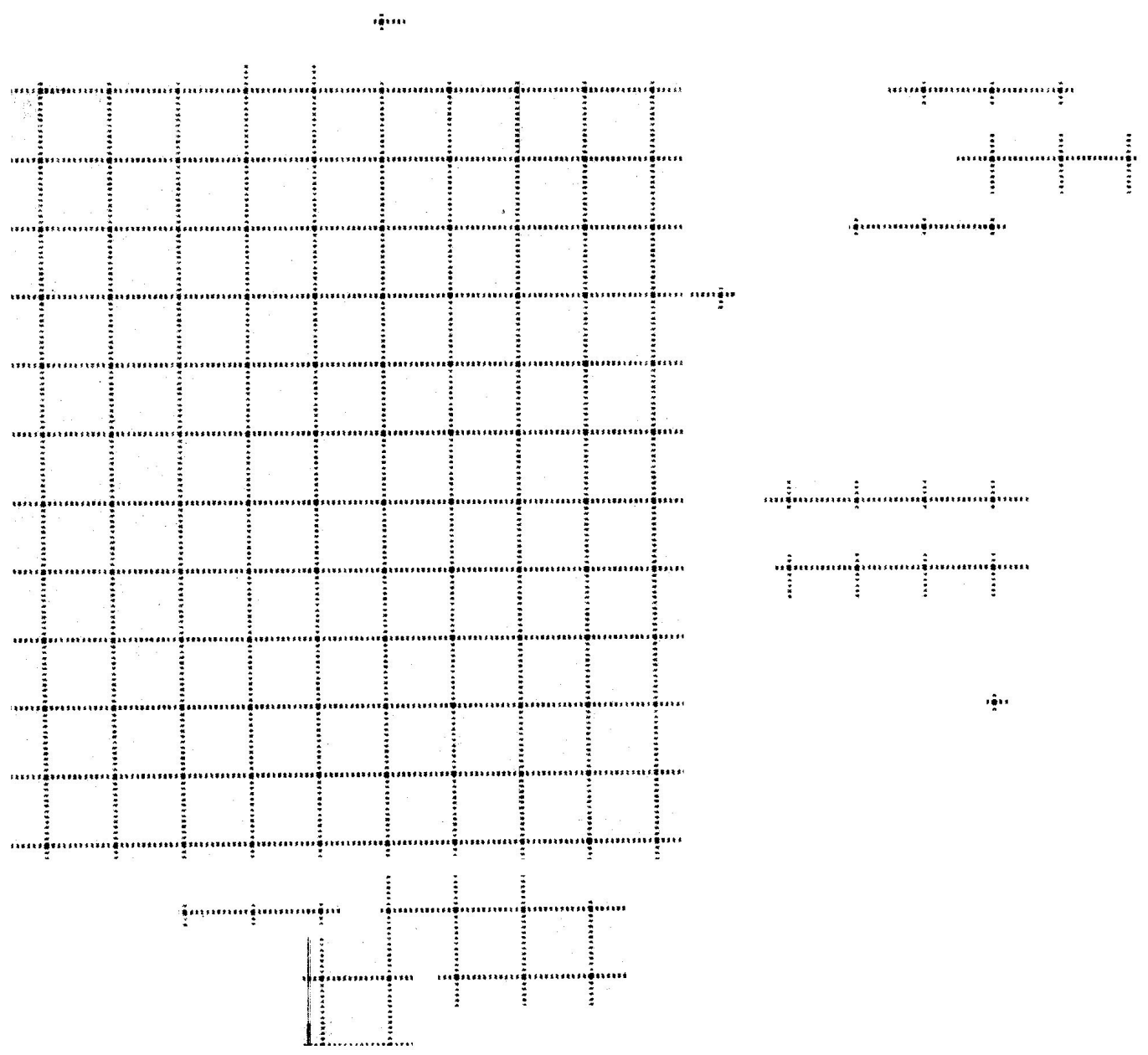


Riffle Pebble Count (Transect method; do 100 pebble counts in riffle habitat only; measure particles at equal increments across multiple line transects within the wetted width of available riffle habitat throughout the reach)

\begin{tabular}{|c|c|c|c|c|c|}
\hline Size Class & $\begin{array}{c}\text { Size } \\
\text { Range }(\mathrm{mm}) \\
\end{array}$ & Tally & Count & Percent & $\begin{array}{c}\text { Cumulative } \\
\text { Percent }\end{array}$ \\
\hline Silt/Clay* & $<0.062$ & & & & \\
\hline Sand $d^{\star \star}$ & $0.063-2$ & & & & \\
\hline Very Fine Gravel & $3-4$ & & & & \\
\hline Fine Gravel & $5-8$ & & & & \\
\hline Medium Gravel & $9-16$ & & & & \\
\hline Coarse Gravel & $17-32$ & & & & \\
\hline Very Coarse Gravel & $33-64$ & & & & \\
\hline Small Cobble & $65-96$ & & & & \\
\hline Medium Cobble & $97-128$ & & & & \\
\hline Large Cobble & $129-180$ & & & & \\
\hline Very Large Cobble & $181-256$ & & & & \\
\hline Small Boulder & $257-512$ & & & & \\
\hline Medium Boulder & $513-1024$ & & & & \\
\hline Large Boulder & $1025-2048$ & & & & \\
\hline Very Large Boulder & $2049-4096$ & & & & \\
\hline Bedrock & $>4097$ & & & & \\
\hline & Totals & & & & \\
\hline \multicolumn{4}{|c|}{ Comments: (record \# of transects and increment size) } & $\begin{array}{l}\% \text { Fines } \\
(<2 \mathrm{~mm}) \\
\end{array}$ & \\
\hline & & & & $\begin{array}{c}\text { \# Size } \\
\text { Classes } \\
\end{array}$ & \\
\hline & & & & D15 & \\
\hline & & & & D50 & \\
\hline & & & & D84 & \\
\hline
\end{tabular}

* Particles feel slick when rubbing between thumb and forefinger

** Particles feel gritty when rubbing between thumb and forefinger 
RIPARIAN VEGETATION COVER: (Record the \% cover of each vegetation type. Consider each vegetative layer separately with a score of $0-100 \%$ for each)

\begin{tabular}{|l|l|}
\hline Riparian Vegetation Cover & Percent Cover \\
\hline Canopy of riparian trees ( $>5 \mathrm{~m}$ high) & \\
\hline $\begin{array}{l}\text { Understory of woody shrubs, saplings, herbs, grasses \& forbs }(0.5 \\
\text { to } 5 \mathrm{~m} \text { high) }\end{array}$ & \\
\hline $\begin{array}{l}\text { Ground cover of woody shrubs seedlings, herbs, grasses \& forbs } \\
(<0.5 \mathrm{~m} \text { high) }\end{array}$ & \\
\hline Barren, bare dirt & \\
\hline
\end{tabular}

METHUUS OF MEASURING AREAL EX'IEN'

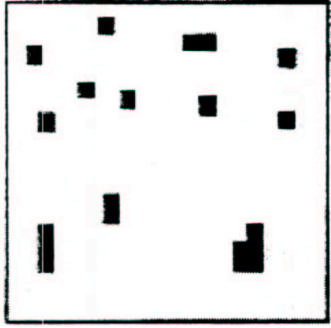

58

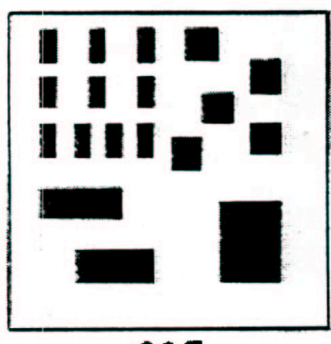

$20 \%$

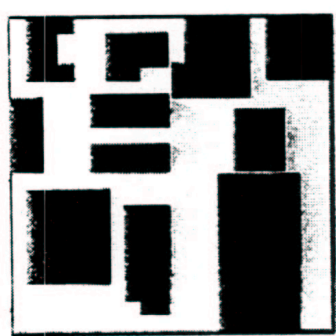

508

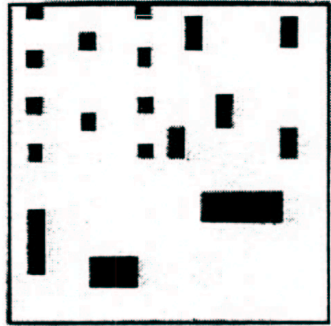

$10 \%$

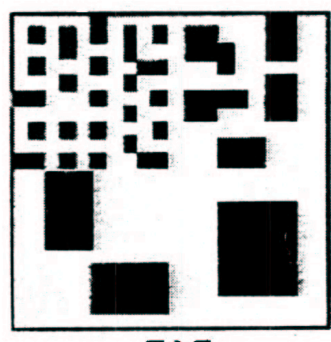

$30 \%$

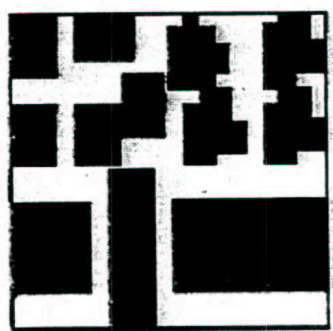

$60 \%$

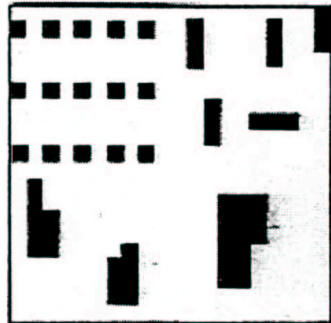

$15 \%$

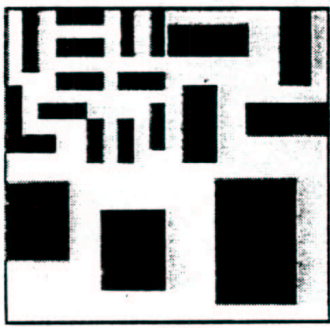

$40 \%$

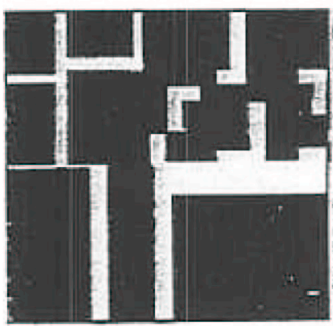

$80 \%$

ïgure 5.9. Chart tor visual estimation of areal coverage. Modified trom Northoote (i979) by permission of Rellim Technical Publications 
REgeneration Potential of RIPARIAN TREes

'.ist the common riparian species in order of most abundant to least, then check the boxes for each age class that is esent)

\begin{tabular}{|c|c|c|c|c|}
\hline Species & $\begin{array}{c}\text { Mature } \\
\text { Trees } \\
\end{array}$ & $\begin{array}{l}\text { Young } \\
\text { Trees } \\
\end{array}$ & Saplings & Seedlings* \\
\hline 1) & & & & \\
\hline 2) & & & & \\
\hline 3) & & & & \\
\hline 4) & & & & \\
\hline 5) & & & & \\
\hline
\end{tabular}

Mature trees $=$ diameter $>40 \mathrm{~cm}\left(16^{\prime \prime}\right) @ 1 \mathrm{~m}$ height

Young trees = diameter $3-40 \mathrm{~cm} @ 1 \mathrm{~m}$ height

Saplings $=$ diameter $<3 \mathrm{~cm}\left(<1.2^{\prime \prime}\right)$

Seedlings $=$ New growth this year; ${ }^{*}$ note if present but don't count as an age class ${ }^{*}$

Age Classes of the Dominant Riparian TRee Species (Check the one that applies)

Species abundant in 3 age classes

Abundant in 2 age classes

Only one age class present.

No regeneration evident, few mature trees found, no saplings or seedlings or if present they are heavily grazed/damaged. 
ADDITIONAL FIELD NOTES: (Note How stream is confined, geomorphic features, streambed structure, habitat variety, zdimentation, flood/drought evidence, fish, frogs, other wildlife, channel modifications etc.) 


\begin{tabular}{|c|c|c|c|c|c|}
\hline & Habitat & & Condition & Category & \\
\hline & Parameter & Optimal & Suboptimal & Marginal & Poor \\
\hline & $\begin{array}{l}\text { 6. Channel } \\
\text { Alteration }\end{array}$ & $\begin{array}{l}\text { Channelization or } \\
\text { dredging absent or } \\
\text { minimal; stream with } \\
\text { normal pattern. }\end{array}$ & $\begin{array}{l}\text { Some channelization } \\
\text { present, usually in areas } \\
\text { of bridge abutments; } \\
\text { evidence of past } \\
\text { channelization, i.e., } \\
\text { dredging, (greater than } \\
\text { past } 20 \text { yr) may be } \\
\text { present, but recent } \\
\text { channelization is not } \\
\text { present. } \\
\end{array}$ & $\begin{array}{l}\text { Channelization may be } \\
\text { extensive; embankments } \\
\text { or shoring structures } \\
\text { present on both banks; } \\
\text { and } 40 \text { to } 80 \% \text { of stream } \\
\text { reach channelized and } \\
\text { disrupted. }\end{array}$ & $\begin{array}{l}\text { Banks shored with } \\
\text { gabion or cement; over } \\
80 \% \text { of the stream reach } \\
\text { channelized and } \\
\text { disrupted. Instream } \\
\text { habitat greatly altered or } \\
\text { removed entirely. }\end{array}$ \\
\hline & SCORE & $\begin{array}{|lllll|}20 & 19 & 18 & 17 & 16 \\
\end{array}$ & $\begin{array}{lllll}15 & 14 & 13 & 12 & 11\end{array}$ & \begin{tabular}{lllll|}
10 & 9 & 8 & 7 & 6 \\
\end{tabular} & $\begin{array}{llllll}5 & 4 & 3 & 2 & 1 & 0\end{array}$ \\
\hline 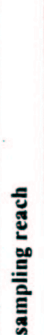 & $\begin{array}{l}\text { 7. Frequency of } \\
\text { Riffles (or bends) }\end{array}$ & $\begin{array}{l}\text { Occurrence of riffles } \\
\text { relatively frequent; ratio } \\
\text { of distance between } \\
\text { riffles divided by width } \\
\text { of the stream }<7: 1 \\
\text { (generally } 5 \text { to } 7 \text { ); } \\
\text { variety of habitat is key. } \\
\text { In streams where riffles } \\
\text { are continuous, } \\
\text { placement of boulders or } \\
\text { other large, natural } \\
\text { obstruction is important. } \\
\end{array}$ & $\begin{array}{l}\text { Occurrence of riffles } \\
\text { infrequent; distance } \\
\text { between riffles divided } \\
\text { by the width of the } \\
\text { stream is between } 7 \text { to } \\
15 .\end{array}$ & $\begin{array}{l}\text { Occasional riffle or } \\
\text { bend; bottom contours } \\
\text { provide some habitat; } \\
\text { distance between riffles } \\
\text { divided by the width of } \\
\text { the stream is between } 15 \\
\text { to } 25 \text {. }\end{array}$ & $\begin{array}{l}\text { Generally all flat water } \\
\text { or shallow riffles; poor } \\
\text { habitat; distance } \\
\text { between riffles divided } \\
\text { by the width of the } \\
\text { stream is a ratio of }>25 \text {. }\end{array}$ \\
\hline$\underline{\tilde{z}}$ & SCORE & $\begin{array}{lllll}20 & 19 & 18 & 17 & 16\end{array}$ & $\begin{array}{lllll}15 & 14 & 13 & 12 & 11\end{array}$ & $\begin{array}{lllll}10 & 9 & 8 & 7 & 6\end{array}$ & $\begin{array}{llllll}5 & 4 & 3 & 2 & 1 & 0\end{array}$ \\
\hline 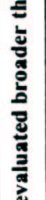 & $\begin{array}{l}\text { 8. Bank Stability } \\
\text { (score each bank) } \\
\text { Note: determine left } \\
\text { or right side by } \\
\text { facing downstream }\end{array}$ & $\begin{array}{l}\text { Banks stable; evidence } \\
\text { of erosion or bank } \\
\text { failure absent or } \\
\text { minimal; little potential } \\
\text { for future problems. } \\
<5 \% \text { of bank affected. } \\
\end{array}$ & $\begin{array}{l}\text { Moderately stable; } \\
\text { infrequent, small areas } \\
\text { of erosion mostly healed } \\
\text { over. } 5-30 \% \text { of bank in } \\
\text { reach has areas of } \\
\text { erosion. }\end{array}$ & $\begin{array}{l}\text { Moderately unstable; } \\
30-60 \% \text { of bank in reach } \\
\text { has areas of erosion; } \\
\text { high erosion potential } \\
\text { during floods. }\end{array}$ & $\begin{array}{l}\text { Unstable; many eroded } \\
\text { areas; "raw" areas } \\
\text { frequent along straight } \\
\text { sections and bends; } \\
\text { obvious bank sloughing; } \\
60-100 \% \text { of bank has } \\
\text { erosional scars. } \\
\end{array}$ \\
\hline 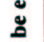 & SCORE (LB) & Left Bank $\quad 109$ & 7 & 4 & 2 \\
\hline 9 & SCORE (RB) & Right Bank $\quad 10 \quad 9$ & $8 \quad 7$ & 3 & 1 \\
\hline & $\begin{array}{l}\text { 9. Vegetative } \\
\text { Protection (score } \\
\text { each bank) }\end{array}$ & \begin{tabular}{|l|} 
More than $90 \%$ of the \\
streambank surfaces and \\
immediate riparian zone \\
covered by native \\
vegetation, including \\
trees, understory shrubs, \\
or nonwoody \\
macrophytes; vegetative \\
disruption through \\
grazing or mowing \\
minimal or not evident; \\
almost all plants allowed \\
to grow naturally. \\
\end{tabular} & $\begin{array}{l}70-90 \% \text { of the } \\
\text { streambank surfaces } \\
\text { covered by native } \\
\text { vegetation, but one class } \\
\text { of plants is not well- } \\
\text { represented; disruption } \\
\text { evident but not affecting } \\
\text { full plant growth. } \\
\text { potential to any great } \\
\text { extent; more than one- } \\
\text { half of the potential } \\
\text { plant stubble height } \\
\text { remaining. } \\
\end{array}$ & $\begin{array}{l}50-70 \% \text { of the } \\
\text { streambank surfaces } \\
\text { covered by vegetation; } \\
\text { disruption obvious; } \\
\text { patches of bare soil or } \\
\text { closely cropped } \\
\text { vegetation common; less } \\
\text { than one-half of the } \\
\text { potential plant stubble } \\
\text { height remaining. }\end{array}$ & $\begin{array}{l}\text { Less than } 50 \% \text { of the } \\
\text { streambank surfaces } \\
\text { covered by vegetation; } \\
\text { disruption of streambank } \\
\text { vegetation is very high; } \\
\text { vegetation has been } \\
\text { removed to } 5 \\
\text { centimeters or less in } \\
\text { average stubble height. }\end{array}$ \\
\hline & SCORE (LB) & Left Bank: $\quad 10 \quad 9$ & 8 & 3 & 0 \\
\hline & SCORE (RB) & Right Bank $\quad 10 \quad 9$ & 7 & 3 & 1 \\
\hline & $\begin{array}{l}\text { 10. Riparian } \\
\text { Vegetative Zone } \\
\text { Width (score each } \\
\text { bank riparian zone) }\end{array}$ & $\begin{array}{l}\text { Width of riparian zone } \\
>18 \text { meters; human } \\
\text { activities (i.e., parking } \\
\text { lots, roadbeds, clear- } \\
\text { cuts, lawns, or crops) } \\
\text { have not impacted zone. } \\
\end{array}$ & $\begin{array}{l}\text { Width of riparian zone } \\
12-18 \text { meters; human } \\
\text { activities have impacted } \\
\text { zone only minimally. }\end{array}$ & $\begin{array}{l}\text { Width of riparian zone } \\
6-12 \text { meters; human } \\
\text { activities have impacted } \\
\text { zone a great deal. }\end{array}$ & $\begin{array}{l}\text { Width of riparian zone } \\
<6 \text { meters: little or no } \\
\text { riparian vegetation due } \\
\text { to human activities. }\end{array}$ \\
\hline & SCORE (LB) & $\begin{array}{lll}\text { Left Bank } \quad 10 \quad 9 \\
\end{array}$ & 7 & 5 & 2 \\
\hline & SCORE (RB) & Right Bank $\quad 109$ & $8 \quad 7$ & 5 & 1 \\
\hline
\end{tabular}

Total Score

Adapted from EPA Rapid Bioassessment Protocols For Use in Streams and Wadeable Rivers: Periphyton, Benthic Macroinvertebrates, and Fish, Second Edition, 1999. 
HABITAT ASSESSMENT FIELD DATA SHEET - HIGH GRADIENT STREAMS

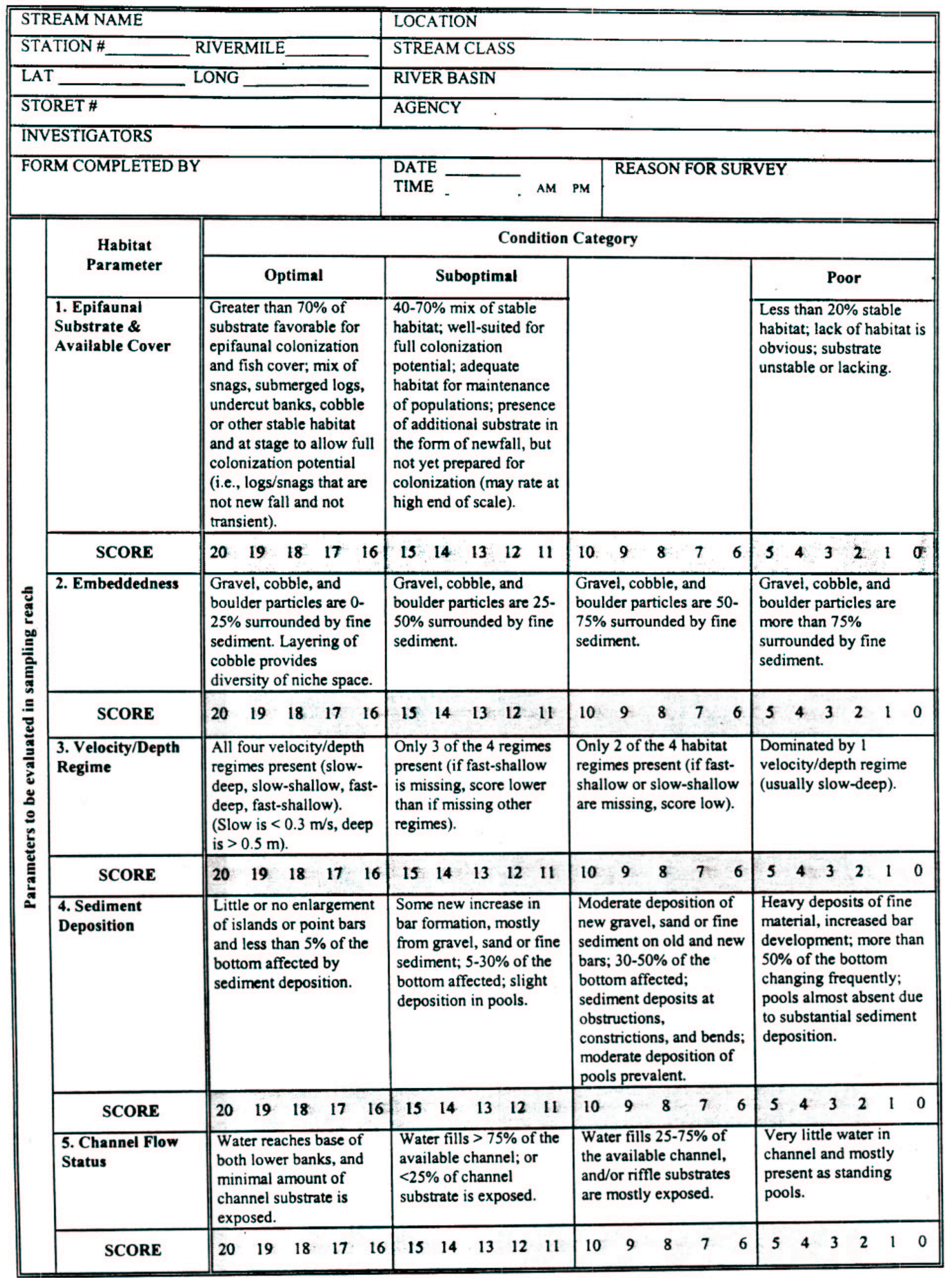

Adapted from EPA Rapid Bioassessment Protocols For Use in Streams and Wadeable Rivers: Periphyton, Benthic Macroinvertebrates, and Fish, Second Edition, 1999. 
APPENDIX B. SAMPLE DATA

\begin{tabular}{|c|c|c|c|c|c|c|c|c|c|c|c|c|c|c|c|c|c|c|c|}
\hline \multirow[b]{3}{*}{ Taxa Name } & \multicolumn{19}{|c|}{ Site and Date } \\
\hline & \multicolumn{4}{|c|}{ Upper Los Alamos } & \multicolumn{4}{|c|}{ Upper Sandia } & \multicolumn{5}{|c|}{ Lower Sandia } & \multicolumn{3}{|c|}{ Starmer's Gulch } & \multicolumn{3}{|c|}{ Pajarito Canyon } \\
\hline & $2 / 97$ & $7 / 01$ & $10 / 01$ & 9/02 & $7 / 01$ & 10/01 & $5 / 02$ & $10 / 02$ & $3 / 96$ & $7 / 01$ & $10 / 01$ & $5 / 02$ & $10 / 02$ & $7 / 94$ & $7 / 01$ & 11/01 & $7 / 94$ & $7 / 01$ & 11/01 \\
\hline \multicolumn{20}{|l|}{ Plecoptera - Stoneflies } \\
\hline Amphinemura banksi & 13 & & 7 & & & & & & & & & & & 227 & 1 & 4 & 1 & 22 & 16 \\
\hline Capniidea & 2 & & 64 & & & 1 & & & & & & & & & & & & & 4 \\
\hline Hesperoperla pacifica & 39 & & & & & & & & & & & & & 7 & 1 & 120 & 44 & & \\
\hline Alloperla severa & 8 & & & & & & & & & & & & & 10 & & & & & \\
\hline \multicolumn{20}{|l|}{ Ephemeroptera - Mayflies } \\
\hline Baetis tricaudatus & 84 & & 4 & 4 & 2 & 7 & & 8 & 156 & 62 & 196 & 5 & 140 & 49 & 27 & 98 & 90 & 32 & 195 \\
\hline Acentrella insignificans & 10 & & & & & 11 & & & & & 7 & & & & 1 & 9 & & 2 & 93 \\
\hline Tricorythodes sp. & & & & & & & & & & 1 & & & 1 & & & & & & \\
\hline Ameletus & & & & & & & & & & & & & & 1 & & & 13 & & \\
\hline Paraleptophlebia & 11 & & & & & & & & & & & & & 1 & & & & & \\
\hline Rhyacophila brunnea cpx. & & & & & & & & & & & & & & & 1 & & & & \\
\hline Glossosomatidae & & & & & & & & & & & & & & & & & & & 1 \\
\hline Hydropsyche sp. & 45 & & & & & 11 & & 6 & 136 & 1 & 66 & 18 & 234 & & & & & & \\
\hline Ochrotrichia sp. & & & & & & & & & & & 10 & & & & & & & 1 & \\
\hline Limnephilidae & 2 & & & & & & & & & & & & & & 2 & & & & \\
\hline Lepidostoma sp. & & & 1 & & & & & & & & 35 & & 1 & & 82 & 2 & & 14 & 8 \\
\hline Hesperophylax sp. & 2 & & & & & & & & 5 & 1 & & 6 & & 14 & 3 & 42 & 10 & & 2 \\
\hline $\begin{array}{l}\text { Hydroptila sp. } \\
\text { Psychoglypha sp. }\end{array}$ & & & & & & & & & & & & & 13 & & & & & 4 & \\
\hline Glossosoma & & & & & & & & & & & & & & & & & 1 & & \\
\hline Ceratopsyche oslari & & & & & & & & & & & & & & & & & 4 & & \\
\hline Ecclisomyia & & & & & & & & & & & & & & & & & 2 & & \\
\hline Micrasema & 42 & & & & & & & & & & & & & & & & & & \\
\hline Leptoceridae & 2 & & & & & & & & & & & & & & & & & & \\
\hline
\end{tabular}




\begin{tabular}{|c|c|c|c|c|c|c|c|c|c|c|c|c|c|c|c|c|c|c|c|}
\hline \multirow[b]{3}{*}{ Taxa Name } & \multicolumn{19}{|c|}{ Site and Date } \\
\hline & \multicolumn{4}{|c|}{ Upper Los Alamos } & \multicolumn{4}{|c|}{ Upper Sandia } & \multicolumn{5}{|c|}{ Lower Sandia } & \multicolumn{3}{|c|}{ Starmer's Gulch } & \multicolumn{3}{|c|}{ Pajarito Canyon } \\
\hline & $2 / 97$ & $7 / 01$ & $10 / 01$ & $9 / 02$ & $7 / 01$ & $10 / 01$ & $5 / 02$ & $10 / 02$ & $3 / 96$ & $7 / 01$ & $10 / 01$ & $5 / 02$ & $10 / 02$ & $7 / 94$ & $7 / 01$ & 11/01 & $7 / 94$ & $7 / 01$ & $11 / 01$ \\
\hline Dolophilodes & 3 & & & & & & & & & & & & & & & & & & \\
\hline Rhyacophilidae & 16 & & & & & & & & & & & & & & & & & & \\
\hline Rhyacophila & & & & & & & & & & & & & & 2 & & & & & \\
\hline $\begin{array}{l}\text { Rhyacophila verrula } \\
\text { Diptera - True Flies }\end{array}$ & 8 & & & & & & & & & & & & & & & & & & \\
\hline Pedicia $\mathrm{sp}$ & & & & & & & & & & & & & & & 2 & & & & \\
\hline Antocha monticola & & & & & & & & & & & 2 & & & 2 & & & & & \\
\hline Dicranota sp. & 8 & & 6 & & & & & & & & & & & 6 & 5 & 55 & 10 & 4 & 19 \\
\hline Tipula sp. & & & & & & 1 & & & & & 2 & & & 1 & & 1 & & & \\
\hline Maruina sp. & & & & & 1 & & & & & & & & & & & & & & \\
\hline Simulium sp. & & & 933 & 684 & 9 & 5 & 3 & & & & 25 & 2 & & 20 & 9 & 3 & 38 & & 153 \\
\hline Diamesinae & & & & 2 & & & & & & & & & & & & & & & 2 \\
\hline Thienemanniella sp. & & & 6 & 1 & & & & & & & & & & & & 8 & & & 2 \\
\hline Diamesa sp. & & & 64 & 8 & & & & & & & & 1 & & & & & 9 & & \\
\hline Odontomesa sp. & & & & & & & & & & & & 2 & & & & & & & \\
\hline Prodiamesa sp. & & & & & & & & & & & & & & & & 2 & & & \\
\hline Tanypodinae & & & & & & & & & & & & 5 & & & & & & & \\
\hline Clinotalypus sp. & & & & & & & & & & & & 4 & & & & & & & \\
\hline Pagastia sp. & 624 & & & & 4 & & 25 & & & 2 & & 2 & & 1108 & 7 & & 20 & 18 & \\
\hline Thienemannimyia sp. & & & 1 & & & 1 & 1 & & & & 10 & 21 & 5 & & & & & & \\
\hline Pseudodiamesa sp. & & & 27 & & & & & & & & & & & 57 & 1 & 9 & & & \\
\hline Chaetocladius sp. & & & & & & & & & & & & & & & & 3 & & & \\
\hline Orthocladius sp. & 5 & & 25 & 1 & & 9 & 1 & & & & & & & 8 & & 3 & 1 & & 47 \\
\hline Hydrobaenus sp. & & & & & & & & & & & & & & & & & & 1 & 1 \\
\hline Brillia sp. & & & & 1 & & & & & & & & & & 23 & 4 & 13 & 2 & 2 & 27 \\
\hline Synorthocladius sp. & 9 & & 6 & & & & & & & & & & 14 & & & & & & 2 \\
\hline Orthocladiinae & & & & 18 & & & 999 & 14 & & & & 38 & 37 & & & & & & \\
\hline Eukiefferiella sp. & 3 & & 64 & 22 & 5 & & 97 & 9 & & 2 & 8 & 32 & 21 & 11 & & 4 & & & 2 \\
\hline Parametriocnemus sp. & & & 1 & 59 & 1 & & 59 & 3 & & & 1 & 2 & & 10 & & & 1 & & 2 \\
\hline Tvetenia $\mathrm{sp}$. & 19 & & 2 & & & & & & & & & & & 51 & & 7 & 1 & & 5 \\
\hline Cricotopus sp. & & & & 1 & 4 & 22 & 61 & & & 1 & & & 1 & 53 & & 1 & & & \\
\hline Corynoneura sp. & & & & & & & & & & & & & & 7 & & 1 & 6 & & \\
\hline Rheocricotopus sp. & 1 & & 1 & & & & & & & & & & & 7 & & & & & \\
\hline
\end{tabular}




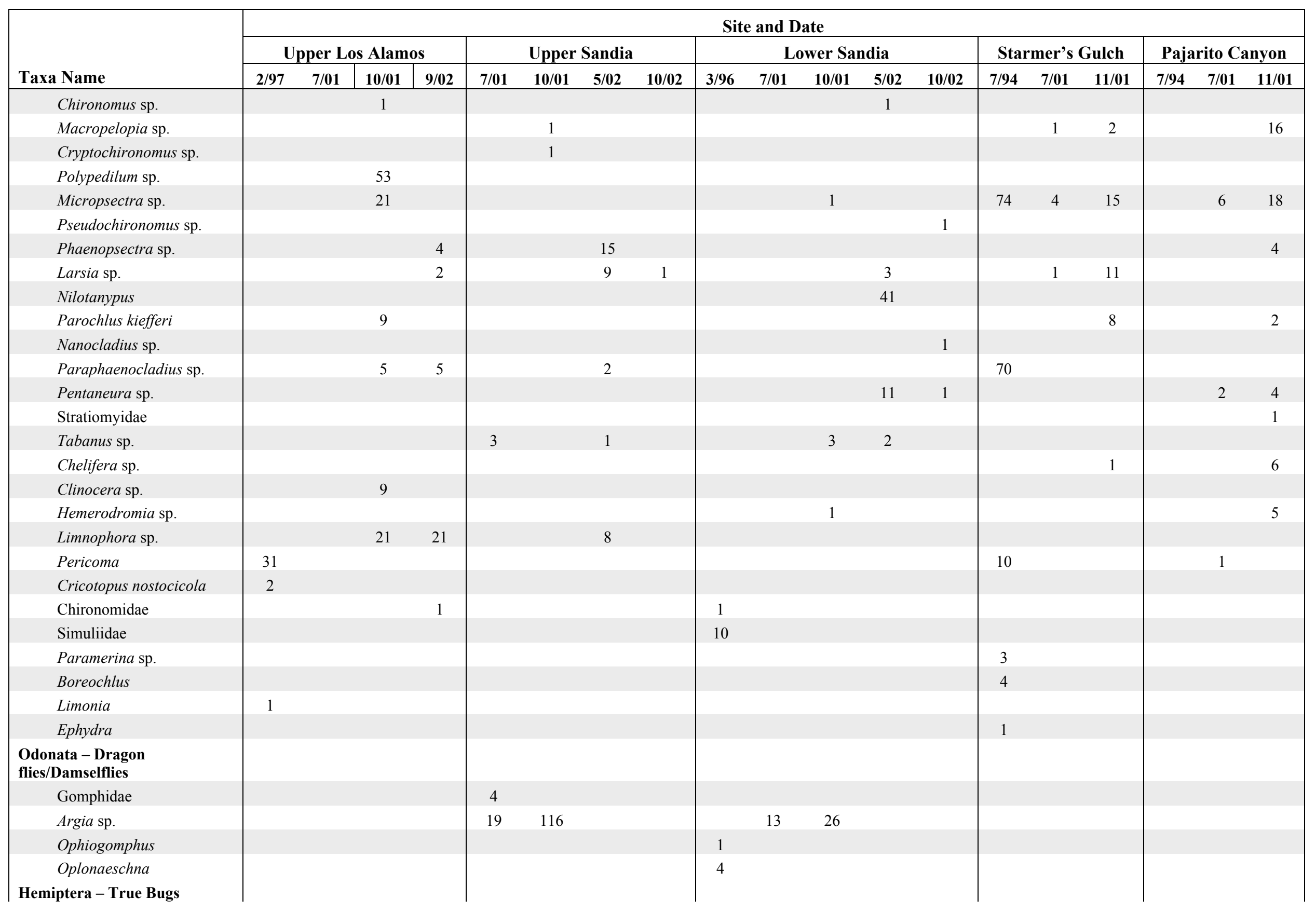




\begin{tabular}{|c|c|c|c|c|c|c|c|c|c|c|c|c|c|c|c|c|c|c|c|}
\hline \multirow[b]{3}{*}{ Taxa Name } & \multicolumn{19}{|c|}{ Site and Date } \\
\hline & \multicolumn{4}{|c|}{ Upper Los Alamos } & \multicolumn{4}{|c|}{ Upper Sandia } & \multicolumn{5}{|c|}{ Lower Sandia } & \multicolumn{3}{|c|}{ Starmer's Gulch } & \multicolumn{3}{|c|}{ Pajarito Canyon } \\
\hline & $2 / 97$ & $7 / 01$ & $10 / 01$ & $9 / 02$ & $7 / 01$ & $10 / 01$ & $5 / 02$ & $10 / 02$ & $3 / 96$ & $7 / 01$ & 10/01 & $5 / 02$ & $10 / 02$ & $7 / 94$ & $7 / 01$ & 11/01 & $7 / 94$ & $7 / 01$ & 11/01 \\
\hline Gerridae & & & & & 1 & & & & & & & & & & & & & & \\
\hline \multicolumn{20}{|l|}{ Microvelia sp. } \\
\hline Boyeria sp. & & & & & & 16 & & & & 2 & 35 & & & & 1 & 1 & & & 6 \\
\hline \multicolumn{20}{|l|}{ Coleoptera - Beetles } \\
\hline Dytiscidae & & & & & & & & & & & & & & & 4 & & & 1 & \\
\hline Dytiscidae A1 & & & & & & & & & & & & & & & & 1 & & & \\
\hline Dytiscus sp. & & & & & & & & & & & & & & & & 10 & & & \\
\hline Helichus sp. & & & & & & & & & & 1 & 1 & & & & & & 1 & & \\
\hline Hydrophilidae & & & & & & & & & & & & & & & 5 & & & & \\
\hline Optioservus sp. & & & & & & & & & 5 & 6 & 6 & & & & & & 69 & 1 & 1 \\
\hline Curculionidae & & & & & & & & & & & & & & 1 & & & & 1 & \\
\hline Staphylinidae & & & & & & & & & & & & & & & 1 & & & & \\
\hline Heterelmis & & & & & & & & & & & & & & 10 & & & & & \\
\hline Cicadellidae & & & 1 & & & & & & & & & & & & & & & & 3 \\
\hline Narpus & & & & & & & & & & & & & & 1 & & & 10 & & \\
\hline \multicolumn{20}{|l|}{ Lepidoptera - Moths } \\
\hline Petrophila sp. & & & & & 1 & 34 & & & & 6 & & & & & & & & & \\
\hline \multicolumn{20}{|l|}{ Collembola - Springtails } \\
\hline Poduridae & & & & & 1 & & & & & & & & & 1 & & 1 & & & 1 \\
\hline \multicolumn{20}{|l|}{ Annelida - Segmented Worms } \\
\hline Tubificidae & & & & & & 3 & & & & & & & & & & 3 & & & \\
\hline Naididae & & & & & & & & & & & & & & & & 11 & & & \\
\hline Lumbricidae & & & 1 & & 5 & 44 & & & & 21 & 35 & & & 2 & 8 & & 59 & & \\
\hline $\begin{array}{l}\text { Lumbriculidae } \\
\text { Platyhelminthes - Flatworms }\end{array}$ & & & & & & & & & 2 & & & & & & & & & & \\
\hline Turbellaria & & & & & & & & & & & & & & 20 & 2 & & 9 & & \\
\hline \multicolumn{20}{|l|}{ Isopoda - Pillbugs } \\
\hline Caecidotea sp. & & & & & & 1 & & & & & & & & & & & & & \\
\hline \multicolumn{20}{|l|}{ Ostracoda - Seed Shrimp } \\
\hline Ostracoda & & & & & & 2 & & & & & 13 & & & & & & & & \\
\hline \multicolumn{20}{|l|}{$\begin{array}{l}\text { Nematomorpha-Gordian } \\
\text { Worms }\end{array}$} \\
\hline Gordius sp. & & & & & & & & & & & & & & & & & & & 1 \\
\hline Nemata - Round Worms & & & & & & & & & & & & & & & & & & & \\
\hline
\end{tabular}




\begin{tabular}{|c|c|c|c|c|c|c|c|c|c|c|c|c|c|c|c|c|c|c|c|}
\hline \multirow[b]{3}{*}{ Taxa Name } & \multicolumn{19}{|c|}{ Site and Date } \\
\hline & \multicolumn{4}{|c|}{ Upper Los Alamos } & \multicolumn{4}{|c|}{ Upper Sandia } & \multicolumn{5}{|c|}{ Lower Sandia } & \multicolumn{3}{|c|}{ Starmer's Gulch } & \multicolumn{3}{|c|}{ Pajarito Canyon } \\
\hline & $2 / 97$ & $7 / 01$ & $10 / 01$ & $9 / 02$ & $7 / 01$ & $10 / 01$ & $5 / 02$ & $10 / 02$ & $3 / 96$ & $7 / 01$ & $10 / 01$ & $5 / 02$ & $10 / 02$ & 7/94 & $7 / 01$ & $11 / 01$ & $7 / 94$ & $7 / 01$ & $11 / 01$ \\
\hline Nemata & & & & & & & & & & & & & & 1 & & & & & \\
\hline
\end{tabular}




\section{APPENDIX C. TAXA ATTRIBUTES AND TOLERANCE VALUES}

\begin{tabular}{|c|c|c|c|c|c|}
\hline $\begin{array}{l}\text { Taxa Name } \\
\text { Plecoptera }\end{array}$ & Habitat & Habit & $\begin{array}{c}\text { Feeding } \\
\text { Group }\end{array}$ & $\begin{array}{l}\text { Tolerance } \\
\text { Value }\end{array}$ & Tolerance Value Source \\
\hline Acroneuria abnormis & Erosional & Clinger & Predator & 0 & WI DNR (Barbour et al. 1999) \\
\hline Alloperla severa & Erosional & Sprawler & Predator & 5 & Wisseman (1996) \\
\hline Amphinemura & Eros/Dep & Sprawler & Shredder & 2 & ID DEP (Barbour et al. 1999) \\
\hline Amphinemura banksi & Eros/Dep & Sprawler & Shredder & 2 & Taxonomic parent's TV \\
\hline Capnia sp. & & & Shredder & 4 & Wisseman (1996) \\
\hline Capniidae & Eros/Dep & Sprawler & Shredder & 4 & Wisseman (1996) \\
\hline Chloroperla & Erosional & Clinger & Predator & 5 & Taxonomic parent's TV \\
\hline Chloroperlidae & Erosional & Clinger & Predator & 5 & Wisseman (1996) \\
\hline Cultus & Erosional & Clinger & Predator & 4 & Wisseman (1996) \\
\hline Cultus aestivalis & Erosional & Clinger & Predator & 4 & Taxonomic parent's TV \\
\hline Despaxia & & & & 0 & ID DEP (Barbour et al. 1999) \\
\hline Hesperoperla pacifica & & Clinger & Predator & 5 & Wisseman (1996) \\
\hline Isoperla & Erosional & Clinger & Predator & 5 & Wisseman (1996) \\
\hline Isoperla fulva & Erosional & Clinger & Predator & 2 & ID DEP (Barbour et al. 1999) \\
\hline Isoperla quinquepunctuata & Erosional & Clinger & Predator & 5 & Taxonomic parent's TV \\
\hline Kogotus & Erosional & Clinger & Predator & 5 & Wisseman (1996) \\
\hline Kogotus modestus & Erosional & Clinger & Predator & 4 & Taxonomic parent's TV \\
\hline Leuctridae & Eros/Dep & Sprawler & Shredder & 3 & Wisseman (1996) \\
\hline Malenka & & Swimmer & & 6 & Wisseman (1996) \\
\hline Malenka coloradensis & & & & 6 & Taxonomic parent's TV \\
\hline Nemoura & Erosional & Sprawler & Shredder & 2 & Taxonomic parent's TV \\
\hline Nemouridae & Eros/Dep & Sprawler & Shredder & 2 & ID DEP (Barbour et al. 1999) \\
\hline Paraleuctra & & & & 0 & ID DEP (Barbour et al. 1999) \\
\hline Paraleuctra vershina & & & & 0 & Taxonomic parent's TV \\
\hline Paraperla & & & & 3 & Wisseman (1996) \\
\hline Paraperla frontalis & & & & 3 & Taxonomic parent's TV \\
\hline Perlodidae & Depositional & Clinger & Predator & 4 & Wisseman (1996) \\
\hline Perlodinae & Erosional & Clinger & Predator & 4 & Wisseman (1996) \\
\hline Podmosta & & & & 3 & Wisseman (1996) \\
\hline Podmosta delicatula & & & & 3 & Taxonomic parent's TV \\
\hline Pteronarcella & Eros/Dep & Clinger & Shredder & 6 & Wisseman (1996) \\
\hline Pteronarcella badia & Eros/Dep & Clinger & Shredder & 6 & Taxonomic parent's TV \\
\hline Pteronarcys & Eros/Dep & Clinger & Shredder & 4 & Wisseman (1996) \\
\hline Pteronarcys californica & Erosional & Clinger & Shredder & 6 & Wisseman (1996) \\
\hline Skwala & & & Predator & 5 & Wisseman (1996) \\
\hline Skwala parallela & & & Predator & 4 & Taxonomic parent's TV \\
\hline Suwalia & & & Predator & 1 & ID DEP (Barbour et al. 1999) \\
\hline Sweltsa coloradensis & Erosional & Clinger & Predator & 5 & Wisseman (1996) \\
\hline Sweltsa sp. & Erosional & Clinger & Predator & 5 & Wisseman (1996) \\
\hline Taeniomena & & & & 2 & ID DEP (Barbour et al. 1999) \\
\hline
\end{tabular}


Taxa Name

Plecoptera (continued)

Zapada cinctipes

Zapada frigida

Ephemeroptera

Acentrella insignifican

Ameletus

Baetis

Baetis bicaudatis

Baetis tricaudatus

Callibaetis

Cinygmula

Drunella

Drunella coloradensis

Drunella doddsi

Drunella grandis (grandis)

Epeorus

Epeorus longimanus

Ephemerella

Ephemerella inermis

Ephemerella infrequens

Ephemerellidae

Heptagenia

Nixe

Nixe simplicoides

Paraleptophlebia

Rhithrogena

Siphlonuridae

Siphlonurus

Siphlonurus occidentalis

Tricorythodes minutus

Tricorythodes sp.

\section{Trichoptera}

Agapetus

Alisotrichia

Amiocentrus

Anagapetus

Arctopsyche

Arctopsyche grandis

Brachycentrus

Brachycentrus americanus

Ceratopsyche oslari

Cheumatopsyche

Chimarra

Dicosmoecus
Habitat

Habit

Erosional Sprawler

Erosional

Erosional

Eros/Dep

Eros/Dep

Eros/Dep

Eros/Dep

Erosional

Erosional

(C)

Erosional

Erosional

Eros/Dep

Eros/Dep

Eros/Dep

Eros/Dep

Erosional

Eros/Dep

Eros/Dep

Erosional

Erosional

Depositional

Depositional

Depositional

Depositional

Sprawler

Swimmer

Swimmer

Swimmer

Swimmer

Swimmer

Swimmer

Clinger

Clinger

Clinger

Clinger

Clinger

Clinger

Clinger

Clinger

Clinger

Clinger

Clinger

Clinger

Clinger

Clinger

Swimmer

Clinger

Swimmer

Swimmer

Swimmer

Sprawler

Sprawler
Erosional

Erosional

Erosional

Erosional

Erosional

Erosional

Erosional

Erosional

Erosional

Erosional

Erosional
Clinger

Clinger

Clinger

Clinger

Clinger

Clinger

Clinger

Clinger

Clinger

Clinger

Sprawler
Feeding

Group

Shredder

Shredder

Collector

Scraper

Collector

Collector

Collector

Collector

Scraper

Scraper

Scraper

Scraper

Scraper

Collector

Collector

Collector

Collector

Collector

Collector

Scraper

Scraper

Scraper

Collector

Collector

Collector

Collector

Collector

Collector

Collector
Tolerance

Value Tolerance Value Source

5 Wisseman (1996)

4 Wisseman (1996)

7 Wisseman (1996)

0

5

2

7

9

6

6

4

5
3

3

6

6

4

4

1

7

1

6

6

6

6

6

6

7

7

7
8

8

8
8

8

5

$\begin{array}{ll}5 & \text { Wisseman (1996) } \\ 4 & \text { Taxonomic parent's }\end{array}$

1

1

ID DEP (Barbour et al. 1999)

Wisseman (1996)

Wisseman (1996)

Wisseman (1996)

ID DEP (Barbour et al. 1999)

Collector 1

Collector 5

\begin{tabular}{cc} 
Collector & 5 \\
Collector & 6 \\
Scraper & 8 \\
\hline
\end{tabular}

Collector 4

$\begin{array}{cc}\text { Collector } & 4 \\ \text { Scraper } & 1\end{array}$


Taxa Name

Trichoptera (continued)

\section{Dolophilodes}

Dolophilodes aequalis

Dolophilodes sortosa

Ecclisomyia

Glossosoma

Glossosomatidae

Gumaga

Helicopsyche

Helicopsyche borealis

Hesperophylax

Hydropsyche

Hydropsyche occentalis

Hydropsyche oslari

Hydropsychidae

Hydroptila

Hydroptilidae

Lepidostoma

Lepidostomatidae

Leptoceridae

Leucotrichia

Limnephilidae

Limnephilus

Micrasema

Namamyia

Ochrotrichia

Odontoceridae

Oecetis

Oligophlebodes

Phylloicus

Polycentropus

Psychoglypha

Psychoronia

Rhyacophila

Rhyacophila acropedes

Rhyacophila brunnea cpx.

Rhyacophila coloradensis

Rhyacophila hyalinata

Rhyacophila valuma

Rhyacophila verrula

Rhyacophilidae

Stactobiella

Wormaldia
Habitat

\section{Erosional}

Erosional

Erosional

Erosional

Erosional

Erosional

Erosional

Erosional

Erosional

Eros/Dep

Erosional

Erosional

Erosional

Erosional

Eros/Dep

Erosional

Eros/Dep

Eros/Dep

Erosional

Erosional

Eros/Dep

Eros/Dep

Eros/Dep

Erosional

Erosiona

Eros/Dep

Erosional

Erosional

Erosional

Erosional

Erosional

Erosional

Erosional

Erosional

Eros/Dep

Erosional
Habit

Clinger

Clinger

Clinger

Clinger

Clinger

Clinger

Sprawler

Clinger

Clinger

Sprawler

Clinger

Clinger

Clinger

Clinger

Clinger

Clinger

Climber

Climber

Clinger

Climber

Clinger

Sprawler

Clinger

Sprawler

Clinger

Clinger

Sprawler

Clinger

Sprawler

Clinger

Clinger

Clinger

Clinger

Clinger

Clinger

Clinger

Clinger

Clinger

Clinger
Feeding Group

Collector

Collector

Collector

Collector

Scraper

Scraper

Shredder

Scraper

Scraper

Shredder

Scraper

Scraper

Scraper

Collector

Collector

\section{Shredder}

Shredder

Scraper

Shredder

Collector

Shredder

Collector

Shredder

Predator

Scraper

Shredder

Predator

Collector

Predator

Predator

Predator

Predator

Predator

Predator

Shredder

Predator

Shredder

Collector
Tolerance

Value Tolerance Value Source

$4 \quad$ Wisseman (1996)

4

4

3

5

5

5

3

3

3

3

5

5

6

4

4

8

4

5

3

4

8

4

4
8

8

5

0

7

7
0

8
4

6
3

3
4
4

4

4

1

5
6

6

4

3

3

4

2

2
5

\author{
Taxonomic parent's TV
}

Taxonomic parent's TV

Wisseman (1996)

Wisseman (1996)

Wisseman (1996)

ID DEP (Barbour et al. 1999)

ID DEP (Barbour et al. 1999)

ID DEP (Barbour et al. 1999)

ID DEP (Barbour et al. 1999)

Wisseman (1996)

ID DEP (Barbour et al. 1999)

ID DEP (Barbour et al. 1999)

Wisseman (1996)

Wisseman (1996)

ID DEP (Barbour et al. 1999)

Wisseman (1996)

ID DEP (Barbour et al. 1999)

ID DEP (Barbour et al. 1999)

Wisseman (1996)

ID DEP (Barbour et al. 1999)

Wisseman (1996)

Wisseman (1996)

ID DEP (Barbour et al. 1999)

Wisseman (1996)

ID DEP (Barbour et al. 1999)

Wisseman (1996)

Taxonomic parent's TV

Wisseman (1996)

Wisseman (1996)

Taxonomic parent's TV

Wisseman (1996)

ID DEP (Barbour et al. 1999)

Wisseman (1996)

Wisseman (1996)

Wisseman (1996)

Wisseman (1996)

Wisseman (1996)

Wisseman (1996)

ID DEP (Barbour et al. 1999)

Wisseman (1996) 


\begin{tabular}{|c|c|c|c|c|c|}
\hline $\begin{array}{l}\text { Taxa Name } \\
\text { Diptera }\end{array}$ & Habitat & Habit & $\begin{array}{l}\text { Feeding } \\
\text { Group }\end{array}$ & $\begin{array}{c}\text { Tolerance } \\
\text { Value }\end{array}$ & Tolerance Value Source \\
\hline Ablabesmyia & Eros/Dep & Sprawler & Predator & 8 & Wisseman (1996) \\
\hline Aedes & & Swimmer & Collector & 8 & MACS (Barbour et al. 1999) \\
\hline Antocha & Erosional & Clinger & Collector & 7 & Wisseman (1996) \\
\hline Antocha monticola & Erosional & Clinger & Collector & 7 & Taxonomic parent's TV \\
\hline Atherix & Eros/Dep & Sprawler & Predator & 7 & Wisseman (1996) \\
\hline Bezzia & & Burrower & Predator & 6 & ID DEP (Barbour et al. 1999) \\
\hline Bittacomorpha & Depositional & Burrower & Collector & 7 & ID DEP (Barbour et al. 1999) \\
\hline Blephariceridae & Erosional & Clinger & Scraper & 3 & Wisseman (1996) \\
\hline Boreochlus & Erosional & Sprawler & Collector & 6 & ID DEP (Barbour et al. 1999) \\
\hline Brachydeutera & & Sprawler & Collector & 9 & Taxonomic parent's TV \\
\hline Brillia sp. & Eros/Dep & Burrower & Shredder & 7 & Wisseman (1996) \\
\hline Cardiocladius & Erosional & Burrower & Predator & 6 & Wisseman (1996) \\
\hline Ceratopogonidae & Depositional & Sprawler & Predator & 6 & ID DEP (Barbour et al. 1999) \\
\hline Chaetocladius & Erosional & Sprawler & Collector & 6 & Wisseman (1996) \\
\hline Chaoborus & & Sprawler & Predator & 8 & Taxonomic parent's TV \\
\hline Chelifera & Depositional & Sprawler & & 7 & Wisseman (1996) \\
\hline Chironomidae & & & & 6 & Wisseman (1996) \\
\hline Chironomidae, Macropelopini & & Sprawler & Predator & 6 & Taxonomic parent's TV \\
\hline Chironomidae, Orthocladiinae & & Burrower & Collector & 5 & Wisseman (1996) \\
\hline Chironomus & Depositional & Burrower & Collector & 10 & Wisseman (1996) \\
\hline Chrysops & Depositional & Sprawler & Predator & 7 & MACS (Barbour et al. 1999) \\
\hline Clinocera & Erosional & Clinger & & 6 & Wisseman (1996) \\
\hline Corynoneura & Depositional & Sprawler & Collector & 6 & Wisseman (1996) \\
\hline Cricotopus & Eros/Dep & Clinger & Shredder & 6 & Wisseman (1996) \\
\hline Cricotopus nostocicola & Eros/Dep & Clinger & Shredder & 6 & Taxonomic parent's TV \\
\hline Cryptochironomus & Depositional & Sprawler & Predator & 8 & ID DEP (Barbour et al. 1999) \\
\hline Cryptotendipes & Depositional & Sprawler & & 6 & WI DNR (Barbour et al. 1999) \\
\hline Culex & & Swimmer & Collector & 8 & MACS (Barbour et al. 1999) \\
\hline Culicidae & Depositional & Swimmer & Collector & 8 & ID DEP (Barbour et al. 1999) \\
\hline Culicoides & & Burrower & Predator & 10 & WI DNR (Barbour et al. 1999) \\
\hline Culiseta & & Swimmer & Collector & 8 & Taxonomic parent's TV \\
\hline Diamesa & Erosional & Sprawler & Collector & 3 & Wisseman (1996) \\
\hline Diamesinae & Eros/Dep & Clinger & Collector & 6 & Taxonomic parent's TV \\
\hline Dicranota & Eros/Dep & Sprawler & Predator & 6 & Wisseman (1996) \\
\hline Dixa & Eros/Dep & Swimmer & Collector & 5 & Wisseman (1996) \\
\hline Dixa californica & Eros/Dep & Swimmer & Collector & 5 & Taxonomic parent's TV \\
\hline Empididae & Eros/Dep & Sprawler & Predator & 6 & Wisseman (1996) \\
\hline Ephydra & Depositional & Sprawler & Shredder & 9 & Taxonomic parent's TV \\
\hline Ephydridae & & Burrower & Collector & 9 & Wisseman (1996) \\
\hline Eukiefferiella & Erosional & Sprawler & Collector & 6 & Wisseman (1996) \\
\hline Hemerodromia & Eros/Dep & Sprawler & Predator & 8 & Wisseman (1996) \\
\hline Hexatoma & Eros/Dep & Burrower & Predator & 5 & Wisseman (1996) \\
\hline Holorusia & Depositional & Burrower & Shredder & 6 & Taxonomic parent's TV \\
\hline
\end{tabular}


Taxa Name

Diptera (continued)

Holorusia grandis

Hydrobaenus

Labrundinia

Larsia

Limnophora

Limnophora aequifrons

Limonia

Macropelopia

Maruina

Micropsectra

Microtendipes

Muscidae

Nanocladius

Nostocladius

Nostococladius

Odontomyia (=Eulalia)

Oreogeton

Orthocladius

Pagastia

Paramerina sp.

Parametriocnemus

Paraphaenocladius

Parochlus kiefferi

Pedicia sp.

Pentaneura

Pericoma

Phaenopsectra

Polypedilum

Procladius

Prodiamesa

Prosimilium

Protanyderus

Pseudochironomus

Pseudodiamesa

Pseudosmittia

Psychodidae

Ptychoptera

Ptychopteridae

Rheocricotopus

Rheotanytarsus

Simuliidae

Simulium

Stempellina

Habitat

Habit

Depositional

Erosiona

Erosional

Erosional

Erosional

Erosional

$\begin{array}{lc} & \text { Burrower } \\ \text { Erosional } & \text { Sprawler } \\ \text { Erosional } & \text { Clinger }\end{array}$

Depositional

Depositional

Eros/Dep

Erosional

Climber

Clinger

Sprawler

Sprawler

thong




\begin{tabular}{|c|c|c|c|c|c|}
\hline Taxa Name & Habitat & Habit & $\begin{array}{c}\text { Feeding } \\
\text { Group }\end{array}$ & $\begin{array}{c}\text { Tolerance } \\
\text { Value }\end{array}$ & Tolerance Value Source \\
\hline \multicolumn{6}{|l|}{ Diptera (continued) } \\
\hline Stempellinealla & Erosional & Sprawler & & 4 & Wisseman (1996) \\
\hline Stratiomyidae & & Sprawler & Collector & 8 & Wisseman (1996) \\
\hline Synorthocladius & & & Collector & 4 & Wisseman (1996) \\
\hline Syrphidae & & & & 10 & ID DEP (Barbour et al. 1999) \\
\hline Tabanidae & Depositional & Sprawler & Predator & 8 & ID DEP (Barbour et al. 1999) \\
\hline Tabanus & Eros/Dep & Sprawler & Predator & 5 & ID DEP (Barbour et al. 1999) \\
\hline Thienemanniella & Eros/Dep & Sprawler & Collector & 6 & Wisseman (1996) \\
\hline Thienemannimyia & Erosional & Sprawler & Predator & 6 & Wisseman (1996) \\
\hline Tipula & Eros/Dep & Burrower & Shredder & 7 & Wisseman (1996) \\
\hline Tipulidae & Eros/Dep & Burrower & Shredder & 6 & Wisseman (1996) \\
\hline Tubifera bastardii & & & & 10 & Taxonomic parent's TV \\
\hline Tvetenia $s p$ & & Sprawler & Collector & 5 & Wisseman (1996) \\
\hline Zavrelia & & Climber & Collector & 6 & Taxonomic parent's TV \\
\hline Zavrelimyia & Erosional & Sprawler & Predator & 7 & Wisseman (1996) \\
\hline \multicolumn{6}{|l|}{ Odonata } \\
\hline Aeshna & & Climber & Predator & 5 & ID DEP (Barbour et al. 1999) \\
\hline Aeshnidae & & Climber & Predator & 3 & ID DEP (Barbour et al. 1999) \\
\hline Anax & & Climber & Predator & 8 & ID DEP (Barbour et al. 1999) \\
\hline Archilestes & Depositional & Climber & Predator & 9 & Taxonomic parent's TV \\
\hline Argia & Eros/Dep & Clinger & Predator & 7 & ID DEP (Barbour et al. 1999) \\
\hline Boyeria & Eros/Dep & Climber & Predator & 3 & Taxonomic parent's TV \\
\hline Coenagrionidae & & Climber & Predator & 9 & Wisseman (1996) \\
\hline Cordulegaster & Depositional & Burrower & Predator & 0 & ID DEP (Barbour et al. 1999) \\
\hline Corduliidae & Depositional & Sprawler & Predator & 2 & ID DEP (Barbour et al. 1999) \\
\hline Enallagma & Depositional & Climber & Predator & 9 & Taxonomic parent's TV \\
\hline Gomphidae & Depositional & Burrower & Predator & 6 & Wisseman (1996) \\
\hline Hetaerina & Eros/Dep & Climber & Predator & 6 & WI DNR (Barbour et al. 1999) \\
\hline Ishnura & Depositional & Climber & Predator & 9 & ID DEP (Barbour et al. 1999) \\
\hline Ishnura perparua & Depositional & Climber & Predator & 9 & Taxonomic parent's TV \\
\hline Leuchorrhina & & Climber & Predator & 9 & Taxonomic parent's TV \\
\hline Libellula & Depositional & Sprawler & Predator & 9 & ID DEP (Barbour et al. 1999) \\
\hline Libellulidae & & Sprawler & Predator & 9 & ID DEP (Barbour et al. 1999) \\
\hline Neurocordulia & Depositional & Climber & Predator & 2 & Taxonomic parent's TV \\
\hline Ophiogomphus & Eros/Dep & Burrower & Predator & 8 & Wisseman (1996) \\
\hline Oplonaeschna & Erosional & Clinger & Predator & 3 & ID DEP (Barbour et al. 1999) \\
\hline Pantala & & Sprawler & Predator & 9 & Taxonomic parent's TV \\
\hline Plathemis & & Sprawler & Predator & 8 & WI DNR (Barbour et al. 1999) \\
\hline Sympetrum & & Sprawler & Predator & 10 & WI DNR (Barbour et al. 1999) \\
\hline Zoniagrion & Depositional & Climber & Predator & 9 & ID DEP (Barbour et al. 1999) \\
\hline \multicolumn{6}{|l|}{ Hemiptera } \\
\hline Ambrysus mormon & Erosional & Clinger & Predator & 5 & Taxonomic parent's TV \\
\hline \multicolumn{6}{|l|}{ Cicadellidae } \\
\hline Corisella & & & Predator & 10 & Taxonomic parent's TV \\
\hline
\end{tabular}


Taxa Name

Hemiptera (continued)

Corixidae

Gerridae

Gerris

Gerris marginatus

Gerris notabilis

Metrobates

Microvelia

Naucoridae

Notonecta

Notonecta undulata

Rhagovelia

Salididae

Sigara

Trepobates

Trichocorixa

Megaloptera

Corydalidae

Neohermes

\section{Coleoptera}

Agabus

Agabus cordatus

Agabus tristus

Ametor

Ametor scabrosus

Amphizoa

Berosus

Berosus styliferous

Carabidae

Cleptelmis addenda

Crenitis

Curculionidae

Cylloepus

Cymbiodyta dorsalis

Deronectes

Deronectes striatellus

Dryopidae

Dubiraphia

Dytiscidae

Dytiscus

Elmidae

Enochrus

Gyrinus

Haliplidae
Habitat

Habit

Swimmer

Skater

Depositional

Depositional

Depositional

Erosional

Depositional

Erosional

Depositional

Depositional

Erosional

Depositional

Depositional

Depositional

Skater

Skater

Skater

Skater

Skater

Clinger

Swimmer

Skater

Climber

Swimmer

Skater

Swimmer

Erosional

Erosional

Clinger

Clinger

Eros/Dep
Eros/Dep
Eros/Dep
Depositional
Depositional
Erosional

Swimmer

Swimmer

Swimmer

Clinger

Clinger

Clinger

Depositional

Swimmer

Depositional

Swimmer

Clinger

Erosional

Depositional

Clinger

Burrower

Clinger

Erosional

Clinger

Depositional

Eros/Dep

Eros/Dep

Erosional

Erosional

Depositional

Depositional

Erosional

Depositional

Depositional

Burrower

Swimmer

Swimmer

Clinger

Clinger

Diver

Swimmer

Clinger

Burrower

Swimmer

Swimmer
Swimmer

Feeding Group

$\begin{array}{ll} & 10 \\ \text { Predator } & 5 \\ \text { Predator } & 5 \\ \text { Predator } & 5 \\ \text { Predator } & 5 \\ \text { Predator } & 5 \\ \text { Predator } & 6 \\ \text { Predator } & 5\end{array}$

Predator

Predator

Predator

Predator

Collector

Predator

Predator

Predator

Predator

Predator

Predator
Predator

8
5

5

Predator

Collector

Collector

Predator

Predra

6

Shredder

5

ID DEP (Barbour et al. 1999)

\begin{tabular}{|c|c|c|}
\hline & 4 & ID DEP (Barbour et al. 1999) \\
\hline & 7 & Taxonomic parent's TV \\
\hline Predator & 5 & ID DEP (Barbour et al. 1999) \\
\hline Predator & 5 & Taxonomic parent's TV \\
\hline \multicolumn{3}{|l|}{ Scraper } \\
\hline & 4 & ID DEP (Barbour et al. 1999) \\
\hline Predator & 8 & Wisseman (1996) \\
\hline Predator & 8 & Wisseman (1996) \\
\hline Collector & 4 & Wisseman (1996) \\
\hline Collector & 5 & ID DEP (Barbour et al. 1999) \\
\hline Predator & 5 & ID DEP (Barbour et al. 1999) \\
\hline Shredder & 7 & ID DEP (Barbour et al. 1999) \\
\hline
\end{tabular}

1 ID DEP (Barbour et al. 1999)

$5 \quad$ ID DEP (Barbour et al. 1999)

5 Taxonomic parent's TV

ID DEP (Barbour et al. 1999)

Wisseman (1996)

ID DEP (Barbour et al. 1999)

ID DEP (Barbour et al. 1999)

ID DEP (Barbour et al. 1999)

Taxonomic parent's TV

Taxonomic parent's TV

Taxonomic parent's TV

Taxonomic parent's TV

MACS (Barbour et al. 1999)

ID DEP (Barbour et al. 1999)

MACS (Barbour et al. 1999)

10 ID DEP (Barbour et al. 1999)

9 MACS (Barbour et al. 1999)

$10 \quad$ ID DEP (Barbour et al. 1999)

$5 \quad$ MACS (Barbour et al. 1999)

ID DEP (Barbour et al. 1999)

0 Taxonomic parent's TV

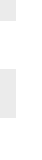




\begin{tabular}{|c|c|c|c|c|c|}
\hline Taxa Name & Habitat & Habit & $\begin{array}{l}\text { Feeding } \\
\text { Group }\end{array}$ & $\begin{array}{c}\text { Tolerance } \\
\text { Value }\end{array}$ & Tolerance Value Source \\
\hline \multicolumn{6}{|l|}{ Coleoptera (continued) } \\
\hline Haliplus & & Swimmer & Shredder & 7 & Taxonomic parent's TV \\
\hline Helichus & Erosional & Clinger & & 5 & WI DNR (Barbour et al. 1999) \\
\hline Helichus striatus & Erosional & Clinger & & 5 & ID DEP (Barbour et al. 1999) \\
\hline Helichus suturalis & Erosional & Clinger & & 5 & WI DNR (Barbour et al. 1999) \\
\hline Helodidae & & Climber & Scraper & & \\
\hline Helophorus & Erosional & Climber & Shredder & 8 & NC (Barbour et al. 1999) \\
\hline Heterelmis & Erosional & Clinger & & 4 & ID DEP (Barbour et al. 1999) \\
\hline Heterlimnius corpulentus & Erosional & Clinger & & 4 & ID DEP (Barbour et al. 1999) \\
\hline Hydaticus & Depositional & Swimmer & Predator & 5 & ID DEP (Barbour et al. 1999) \\
\hline Hydrobius & & Climber & & 8 & ID DEP (Barbour et al. 1999) \\
\hline Hydrochus & Erosional & Climber & Shredder & 7 & Taxonomic parent's TV \\
\hline Hydrophilidae & Depositional & Diver & Collector & 7 & Wisseman (1996) \\
\hline Hydroporus & Depositional & Swimmer & Predator & 5 & ID DEP (Barbour et al. 1999) \\
\hline Hydroporus vilis & Depositional & Swimmer & Predator & 5 & ID DEP (Barbour et al. 1999) \\
\hline Hygrotus & Depositional & Swimmer & Predator & 8 & Taxonomic parent's TV \\
\hline Laccophilus & Depositional & Swimmer & & 5 & ID DEP (Barbour et al. 1999) \\
\hline Microcylloepus & Eros/Dep & Clinger & & 4 & ID DEP (Barbour et al. 1999) \\
\hline Narpus & Erosional & Clinger & & 4 & ID DEP (Barbour et al. 1999) \\
\hline Narpus concolor & Erosional & Clinger & & 4 & ID DEP (Barbour et al. 1999) \\
\hline Optioservus & Eros/Dep & Clinger & Scraper & 7 & Wisseman (1996) \\
\hline Optioservus castanipennis & Eros/Dep & Clinger & Scraper & 4 & ID DEP (Barbour et al. 1999) \\
\hline Optioservus divergens & Eros/Dep & Clinger & Scraper & 4 & ID DEP (Barbour et al. 1999) \\
\hline Peltodytes & Erosional & Swimmer & Shredder & 7 & OH (Barbour et al. 1999) \\
\hline Phytonomus & & Clinger & Shredder & & \\
\hline \multicolumn{6}{|l|}{ Prionocyphon } \\
\hline Psephenidae & Erosional & Clinger & Scraper & 4 & ID DEP (Barbour et al. 1999) \\
\hline Psphenus & Erosional & Clinger & Scraper & 4 & ID DEP (Barbour et al. 1999) \\
\hline Rhantus & Depositional & Swimmer & Predator & 8 & Taxonomic parent's TV \\
\hline Rhizelmis & Erosional & Clinger & & 1 & ID DEP (Barbour et al. 1999) \\
\hline Staphylinidae & & Clinger & Predator & 8 & ID DEP (Barbour et al. 1999) \\
\hline Zaitzevia & Erosional & Clinger & & 7 & Wisseman (1996) \\
\hline Zaitzevia parvula & Erosional & Clinger & & 7 & Taxonomic parent's TV \\
\hline Lepidoptera & & & & 6 & ID DEP (Barbour et al. 1999) \\
\hline Noctuidae & & Burrower & Shredder & 6 & Taxonomic parent's TV \\
\hline Ostrinia & & Burrower & Shredder & 5 & ID DEP (Barbour et al. 1999) \\
\hline Paraponyx & & Climber & Shredder & 5 & MACS (Barbour et al. 1999) \\
\hline Parargyractis & & Climber & Shredder & 6 & Taxonomic parent's TV \\
\hline Parargyractis kearfottalis & & Climber & Shredder & 5 & Taxonomic parent's TV \\
\hline Petrophila & & Climber & Shredder & 7 & Wisseman (1996) \\
\hline Pyralidae & & Climber & Shredder & 5 & ID DEP (Barbour et al. 1999) \\
\hline \multicolumn{6}{|l|}{ Collembola } \\
\hline Isotomidae & & Skater & & & \\
\hline Poduridae & & Skater & Collector & 10 & ID DEP (Barbour et al. 1999) \\
\hline
\end{tabular}




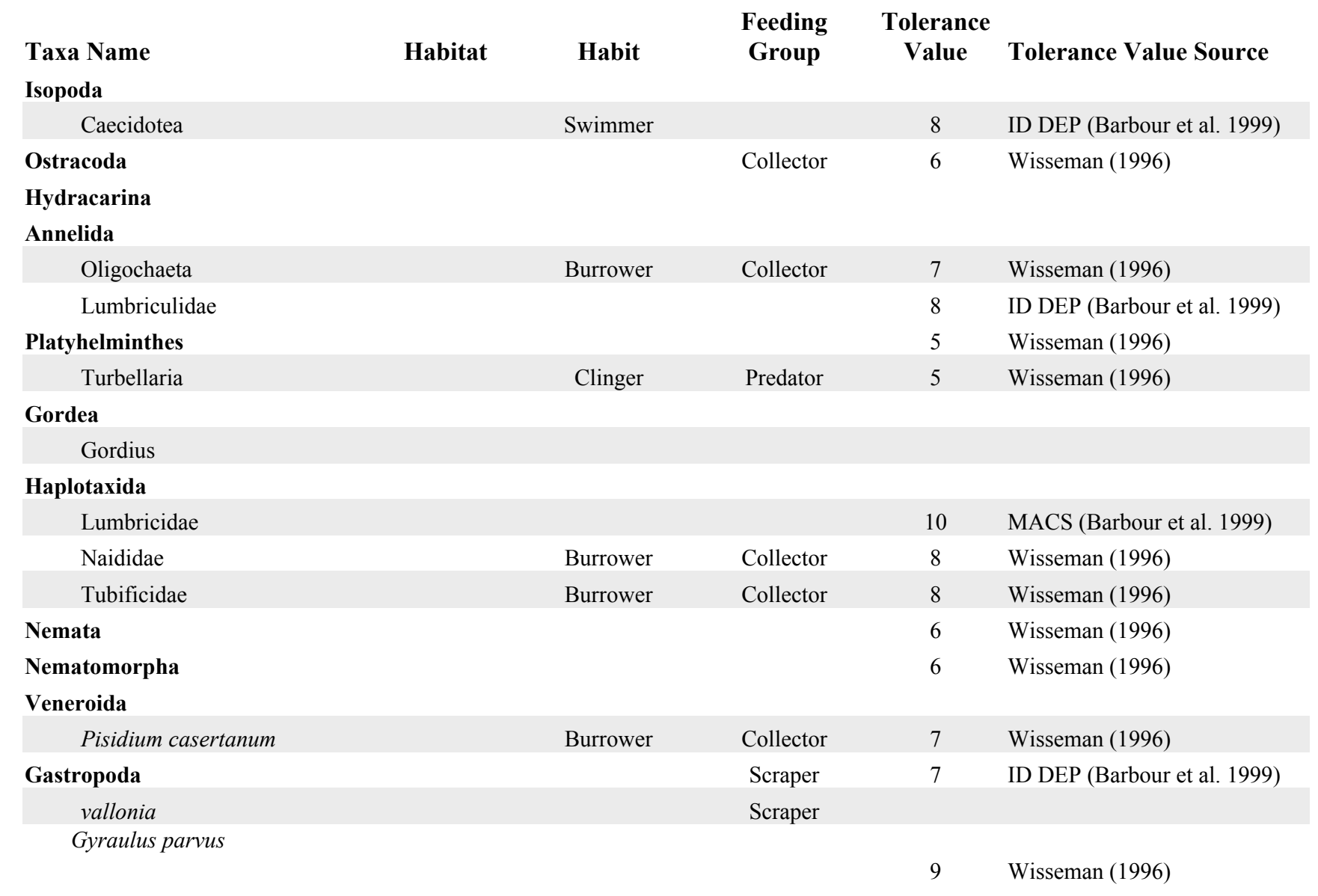




\section{APPENDIX D. MACROINVERTEBRATE METRICS}

Individual and average metric scores for macroinvertebrate samples.

\begin{tabular}{|c|c|c|c|c|c|c|c|c|c|c|c|c|c|c|c|}
\hline \multirow[t]{3}{*}{ Metrics } & \multicolumn{15}{|c|}{ Standardized scores for individual macroinvertebrate metrics and overall Stream Condition Index score. } \\
\hline & \multicolumn{4}{|c|}{ Upper Sandia } & \multicolumn{5}{|c|}{ Lower Sandia } & \multicolumn{3}{|c|}{ Starmer's Gulch } & \multicolumn{3}{|c|}{ Pajarito } \\
\hline & $07 / 01$ & $10 / 01$ & $\mathbf{0 5} / \mathbf{0 2}$ & $10 / 02$ & $03 / 96$ & $07 / 01$ & $10 / 01$ & $05 / 02$ & $10 / 02$ & $07 / 94$ & 07/01 & 11/01 & $07 / 94$ & $07 / 01$ & 11/01 \\
\hline \multicolumn{16}{|l|}{$\begin{array}{l}\text { LOW ELEVATION- } \\
\text { SMALL CATCHMENT } \\
\text { SITES }\end{array}$} \\
\hline \multicolumn{16}{|l|}{ Spring/Fall Samples } \\
\hline$\%$ sprawler & & 14.347 & 39.285 & 24.426 & 4.934 & & 14.940 & 100 & 34.572 & & & 100 & & & 65.176 \\
\hline hydropsychidae to EPT \% & & 63.333 & 63.333 & 57.143 & 54.209 & & 78.710 & 37.931 & 39.846 & & & 100 & & & 100 \\
\hline intolerant taxa & & 7.692 & 7.692 & 7.692 & 7.692 & & 7.692 & 15.385 & 7.692 & & & 15.385 & & & 15.385 \\
\hline$\%$ scraper & & 8.786 & 2.508 & 8.158 & 100 & & 33.841 & 29.794 & 99.244 & & & 0.512 & & & 2.464 \\
\hline$\%$ shredder & & 68.943 & 15.431 & 82.967 & 5.314 & & 30.779 & 8.621 & 14.648 & & & 64.029 & & & 29.858 \\
\hline \multicolumn{16}{|l|}{ Summer samples } \\
\hline hydropsychidae to EPT \% & 100 & & & & & 98.462 & & & & 100 & 100 & & 97.980 & 100 & \\
\hline intolerant taxa & 0.000 & & & & & 7.692 & & & & 23.077 & 23.077 & & 30.769 & 15.385 & \\
\hline$\%$ scraper & 3.808 & & & & & 14.150 & & & & 0.122 & 0.000 & & 43.585 & 2.115 & \\
\hline$\%$ shredder & 28.329 & & & & & 6.017 & & & & 58.012 & 100 & & 10.160 & 100 & \\
\hline Average Score & 33.034 & 32.620 & 25.650 & 36.077 & 34.430 & 31.580 & 33.192 & 38.346 & 39.200 & 45.320 & 55.769 & 55.985 & 45.623 & 54.375 & 42.576 \\
\hline
\end{tabular}

U) HIGH ELEVATION-

\begin{tabular}{lcccc} 
HIGH ELEVATION- & \multicolumn{4}{c}{ Upper Los Alamos } \\
\cline { 2 - 5 } SMALL CATCHMENT & $\mathbf{0 2 / 9 7}$ & $\mathbf{0 7 / 0 1}$ & $\mathbf{1 0 / 0 1}$ & $\mathbf{0 9 / 0 2}$ \\
\hline SITES & 96.774 & -- & 80.645 & 61.290 \\
Eumber of taxa & 57.143 & -- & 14.286 & 14.286 \\
Diptera taxa & 100 & -- & 100 & 100 \\
Plecoptera taxa & 71.429 & -- & 28.571 & 0.000 \\
Shannon Diversity Index & 68.830 & -- & 49.900 & 35.618 \\
Pielou's Evenness Index & 52.643 & -- & 37.371 & 28.346 \\
\% Plecoptera & 19.866 & -- & 19.277 & 0.000 \\
\# intolerant taxa & 15.385 & -- & 23.077 & 7.692 \\
\% shredder individuals & 21.359 & -- & 31.927 & 0.390 \\
\# shredder taxa & 100 & -- & 66.667 & 16.667 \\
\# sprawler taxa & 100 & -- & 100 & 100 \\
\% sprawler individuals & 16.802 & -- & 66.406 & 35.879 \\
\% Swimmer individuals & 19.366 & -- & 0.636 & 9.949 \\
\hline Average Score & $\mathbf{5 6 . 8 9 2}$ & $\mathbf{0}$ & $\mathbf{4 7 . 5 9 7}$ & $\mathbf{3 1 . 5 4 7}$
\end{tabular}

Average Score 
This report has been reproduced directly from the best available copy. It is available electronically on the Web (http://www.doe.gov/bridge).

Copies are available for sale to U.S. Department of Energy employees and contractors from:

Office of Scientific and Technical Information P.O. Box 62

Oak Ridge, TN 37831

(865) 576-8401

Copies are available for sale to the public from: National Technical Information Service

U.S. Department of Commerce

5285 Port Royal Road

Springfield, VA 22161

(800) 553-6847 


\section{Los Alamos}

NATIONAL LABORATORY

EST.1943 